\title{
Taxonomy and phylogeny of the Leptographium procerum complex, including Leptographium sinense sp. nov. and Leptographium longiconidiophorum sp. nov.
}

\author{
Mingliang Yin, Tuan A. Duong, Michael J. Wingfield, XuDong Zhou, \\ Z. Wilhelm de Beer
}

\begin{abstract}
Leptographium procerum (Ophiostomatales, Ascomycota) is a well-known fungal associate of pine root-infesting bark beetles and weevils, occurring in several countries of the world. The fungus is not a primary pathogen but has been associated with white pine root decline in the USA and with serious damage caused by the introduced red turpentine beetle (RTB) Dendroctonus valens in China. Several species closely related to $L$. procerum have been described during the past decade. The aim of this study was to reevaluate species boundaries in the $L$. procerum complex using multigene phylogenetic analyses and morphological comparisons. Phylogenetic analyses of seven gene regions (ITS2-LSU, actin, $\beta$-tubulin, calmodulin, translation elongation factor $1-\alpha$, and the mating type genes MAT1-1-3 and MAT1-2-1) distinguished
\end{abstract}

M. Yin · M. J. Wingfield · X. Zhou · Z. W. de Beer ( $₫)$ Department of Microbiology and Plant Pathology, Forestry and Agricultural Biotechnology Institute (FABI), University of Pretoria, Pretoria 0002, Gauteng Province, South Africa

e-mail: Wilhelm.DeBeer@fabi.up.ac.za

M. Yin $\cdot$ X. Zhou

China Eucalypt Research Centre (CERC), Chinese

Academy of Forestry (CAF),

Zhanjiang 524022, Guangdong Province, China between nine species in the complex. These included $L$. procerum, L. bhutanense, $L$. gracile, L. profanum, L. pini-densiflorae, $L$. sibiricum, $L$. sinoprocerum, as well as two new species described here as Leptographium sinense sp. nov. from Hylobitelus xiaoi on Pinus elliottii in China, and Leptographium longiconidiophorum sp. nov. from Pinus densiflora in Japan. Leptographium latens is reduced to synonymy with $L$. gracile, and an epitype is designated for $L$. procerum, because a living culture associated with the holotype of L. procerum did not exist. Amplification patterns of the mating type genes suggest that all known species in the $L$. procerum complex are heterothallic, although sexual states have not been observed for any of the species. The results also suggest that Eastern Asia is most probably the centre of species diversity for the L. procerum complex.

\footnotetext{
T. A. Duong

Department of Genetics, Forestry and Agricultural

Biotechnology Institute (FABI), University of Pretoria, Pretoria 0002, Gauteng Province, South Africa

Present Address:

X. Zhou

FuturaGene Biotechnology (Shanghai) Co., Ltd.,

Shanghai 200233, China
} 
Keywords Bark beetle associates - Epitype · Leptographium · Ophiostomatales · Phylogeny · Taxonomy

\section{Introduction}

The genus Leptographium Lagerb. \& Melin was first described in 1927, with L. lundbergii, the causal agent of sapstain on pine timber, as the type species (Lagerberg et al. 1927). Leptographium spp. are characterized by mononematous, darkly pigmented conidiophores giving rise to brush-like conidiogenous structures that produce conidia in slimy droplets, facilitating insect dispersal (Jacobs and Wingfield 2001). Under the dual nomenclature system, Leptographium has been considered one of several anamorph genera in the Ophiostomatales (Wingfield 1993), and the sexual states of Leptographium spp. were treated under the genus Grosmannia Goid. (Zipfel et al. 2006). In 2011, dual nomenclature was abandoned (Hawksworth 2011) and the newly proposed one fungus one name principles require that the oldest genus name, in this case Leptographium (Lagerberg et al. 1927), should take preference over the younger name, Grosmannia (Goidànich 1936), irrespective of morph (De Beer and Wingfield 2013).

One of the Leptographium species that has gained most attention in terms of research during recent years is Leptographium procerum, which was first described from Pinus banksiana, P. resinosa, and $P$. strobus in 1962 in North America (Kendrick 1962). The fungus was associated with a disease known as white pine root decline (WPRD) that resulted in significant economic losses in the Christmas tree industry in North Central and Eastern America (Lackner and Alexander 1982; Alexander et al. 1988). However, Wingfield (1986) and Wingfield et al. (1988) argued strongly that the fungus was unlikely to play a primary role in tree death and that it was most likely a resinophillic fungus carried by insects that feed on stressed pine roots. Symptoms similar to those of WPRD were reported by Shaw and Dick (1979) in New Zealand and L. procerum was considered as possibly contributing to a root disease complex. More recently, L. procerum has been reported in association with root-infesting bark beetles from declining pines in the southeastern USA, although inoculation studies suggest that the fungus is not a serious pathogen in this area (Matusick et al. 2012). In all the above-mentioned studies, the identification of L. procerum was based on morphological characters of the fungus, and identities have yet to be confirmed based on DNA sequence data. In Europe, several recent studies showed that $L$. procerum is a common associate of several bark beetle and weevil species, occurring together with other ophiostomatoid fungi. The fungus was isolated from the roots of Pinus sylvestris and soil environments in Poland and identified based on ITS and $\beta$-tubulin sequences (Jankowiak et al. 2012; Jankowiak and Bilański 2013a, b, c).

In $2008, L$. procerum was reported for the first time from China as an associate of the red turpentine beetle Dendroctonus valens ( $\mathrm{Lu}$ et al. 2008), which is thought to have been introduced into that country from North America (Cognato et al. 2005). In northern China this beetle-fungus combination has contributed to the mortality of more than a half million hectares of native pine forests (Miao et al. 2001; Sun et al. 2013). Pathogenicity trials conducted in China on $P$. tabuliformis suggested that the fungus might be more pathogenic to pines in that country than in its native range in North America ( $\mathrm{Lu}$ et al. 2010; Sun et al. 2013). The identity of L. procerum in China has been confirmed using DNA sequence analyses, which also confirmed its relatedness to several other species in the genus (Lu et al. 2008; 2009a, b; Taerum et al. 2013). In another study, Duong et al. (2013) characterized the mating type genes of $L$. procerum and its close relative, L. profanum, showing that both species are heterothallic.

De Beer and Wingfield (2013) defined ten species complexes in Leptographium sensu lato. In one of these complexes, L. procerum was the oldest known species and thus became the name-bearing species of the complex. At present, the L. procerum complex includes eight species (Linnakoski et al. 2012). Interestingly, apart from L. procerum (Kendrick 1962) and $L$. profanum (Jacobs et al. 2006) described from USA, and L. sibiricum from Russia (Jacobs et al. 2000), all other species in the complex have been described from East Asia (Linnakoski et al. 2012). Leptographium pinidensiflorae was described from Japan (Masuya et al. 2000), L. bhutanense from Bhutan (Zhou et al. 2008), and $L$. sinoprocerum (Lu et al. 2008), L. gracile and $L$. latens (Paciura et al. 2010) from China.

The three gene regions, the internal transcribed spacer region 2 and partial large subunit of the 
ribosomal DNA (ITS2-LSU), $\beta$-tubulin $(\beta T)$ and translation elongation factor- 1 alpha (TEF-1 $\alpha$ ), that have typically been used for species delineation in Leptographium during the past decade, have also been used to identify $L$. procerum from China ( $\mathrm{Lu}$ et al. 2008; 2009a, b; Taerum et al. 2013) as well as some of the new species in the complex. However, Paciura et al. (2010) and Linnakoski et al. (2012) showed that the ITS2-LSU and $\beta$ T gene regions have limitations in distinguishing closely related species in the L. procerum complex. Duong et al. (2012) thus sequenced an additional two gene regions, calmodulin (CAL) and actin (ACT) and with sequences for five gene regions, were able to successfully delineate morphologically similar but cryptic species in the neighboring $G$. serpens complex in Leptographium s. $l$.

The aims of this study were to reevaluate the phylogenetic relationships and delineation of all species previously reported in the $L$. procerum complex, applying the five gene regions used by Duong et al. (2012). In addition, we used the recently developed diagnostic markers for the mating type genes MAT1-1-3 and MAT1-2-1 to identify the mating types for all isolates included in this study.

\section{Materials and methods}

Fungal isolates

All isolates used in the study are listed in Table 1. These were obtained from the culture collection (CMW) of the Forestry and Agricultural Biotechnology Institute (FABI), University of Pretoria, South Africa. Ex-type isolates of new species described in this study were deposited in the Centraalbureau voor Schimmelcultures (CBS), Utrecht, the Netherlands, while type specimens were deposited in the National Collection of Fungi (PREM), Pretoria, South Africa. Taxonomic novelties and typification events (Robert et al. 2013) were registered in MycoBank.

DNA extraction, PCR and sequencing

DNA extractions were made using fresh mycelium (ca. $100 \mathrm{mg}$ ) from isolates that had been incubated in $2 \%$ liquid malt extract medium (20 g malt extract, Biolab, South Africa and 1,000 $\mathrm{ml}$ deionized water) for $4-5$ days at $25{ }^{\circ} \mathrm{C}$ in the dark. PrepMan ${ }^{\circledR}$ Ultra
Sample Preparation Reagent (Applied Biosystems, Foster City, California, USA) was used for DNA extraction, following the manufacturer's protocols.

Seven gene regions were amplified for sequencing and phylogenetic analyses, including ITS2-LSU, ACT, $\beta T$, CAL, TEF-1 $\alpha$, MAT1-1-3 and MAT1-2-1. The following primers were used: ITS3 \& LR3 (White et al. 1990) for ITS2-LSU, Lepact-F \& Lepact-R (Lim et al. 2004) for ACT, T10 (O’Donnell and Cigelnik 1997) \& Bt2b (Glass and Donaldson 1995) for $\beta$ T, CL2F \& CL2R (Duong et al. 2012) for CAL, EF1-F \& EF2-R (Jacobs et al. 2004) for TEF-1 $\alpha$, Oph-MAT1F1 \& OphMAT1R2 (Duong et al. 2014) for MAT1-1-3, and OphHMG1 (5'- CGYAAGGAYMAYCACAAGGC - $\left.3^{\prime}\right) \&$ Oph-HMG2 (5'- GGRTGAAGMMKCTCAACCTG $3^{\prime}$ ) (Duong et al. unpublished) for MAT1-2-1.

PCR reactions were conducted in $25 \mu \mathrm{L}$ reaction mixtures containing $5 \mu \mathrm{L}$ of Mytaq buffer (including $\mathrm{MgCl}_{2}$, dNTPs and reaction buffer), $0.5 \mu \mathrm{L}$ of Mytaq polymerase (Bioline, USA), $0.5 \mu \mathrm{L}$ of each primer $(10 \mu \mathrm{M}), 2 \mu \mathrm{L}$ of DNA, and $16.5 \mu \mathrm{L}$ of PCR grade water. Amplification for ITS2-LSU, ACT, $\beta$ T, CAL, MAT1-1-3 and MAT1-2-1 gene regions was as follows: an initial denaturation step at $95^{\circ} \mathrm{C}$ for $3 \mathrm{~min}$, followed by 35 cycles of $95{ }^{\circ} \mathrm{C}$ for $30 \mathrm{~s}, 55-52{ }^{\circ} \mathrm{C}$ for $30 \mathrm{~s}$ and $72{ }^{\circ} \mathrm{C}$ for $40 \mathrm{~s}$, and a final chain elongation at $72{ }^{\circ} \mathrm{C}$ for $8 \mathrm{~min}$. The TEF- $1 \alpha$ gene region was amplified using an initial denaturation step at $95{ }^{\circ} \mathrm{C}$ for $3 \mathrm{~min}$, followed by 35 cycles of $95{ }^{\circ} \mathrm{C}$ for $30 \mathrm{~s}, 55-52{ }^{\circ} \mathrm{C}$ for $45 \mathrm{~s}$ and $72{ }^{\circ} \mathrm{C}$ for $1 \mathrm{~min}$, and a final elongation at $72{ }^{\circ} \mathrm{C}$ for $8 \mathrm{~min}$.

For DNA Sequencing, PCR products were purified using the High Pure PCR Product Purification Kit (Roche Applied Science, Mannheim, Germany) following the manufacturer's protocols. Sequencing PCRs were carried out using the same primer pairs that were used for PCR, together with the Big Dye Terminator 3.1 cycle sequencing premix kit (Applied Biosystems, Foster City, California, USA). The analyses of sequencing PCR products were done on ABI PRISM 3100 Genetic Analyzer (Applied Biosystems, Foster City, California, USA). Forward and reverse sequences of each isolate were assembled with CLC Main Workbench 6.0 (CLC Bio, Aarhus, Denmark) to produce a consensus sequence.

Phylogenetic analyses

A total of seven different datasets were prepared for phylogenetic analyses. The ITS2-LSU sequences of 


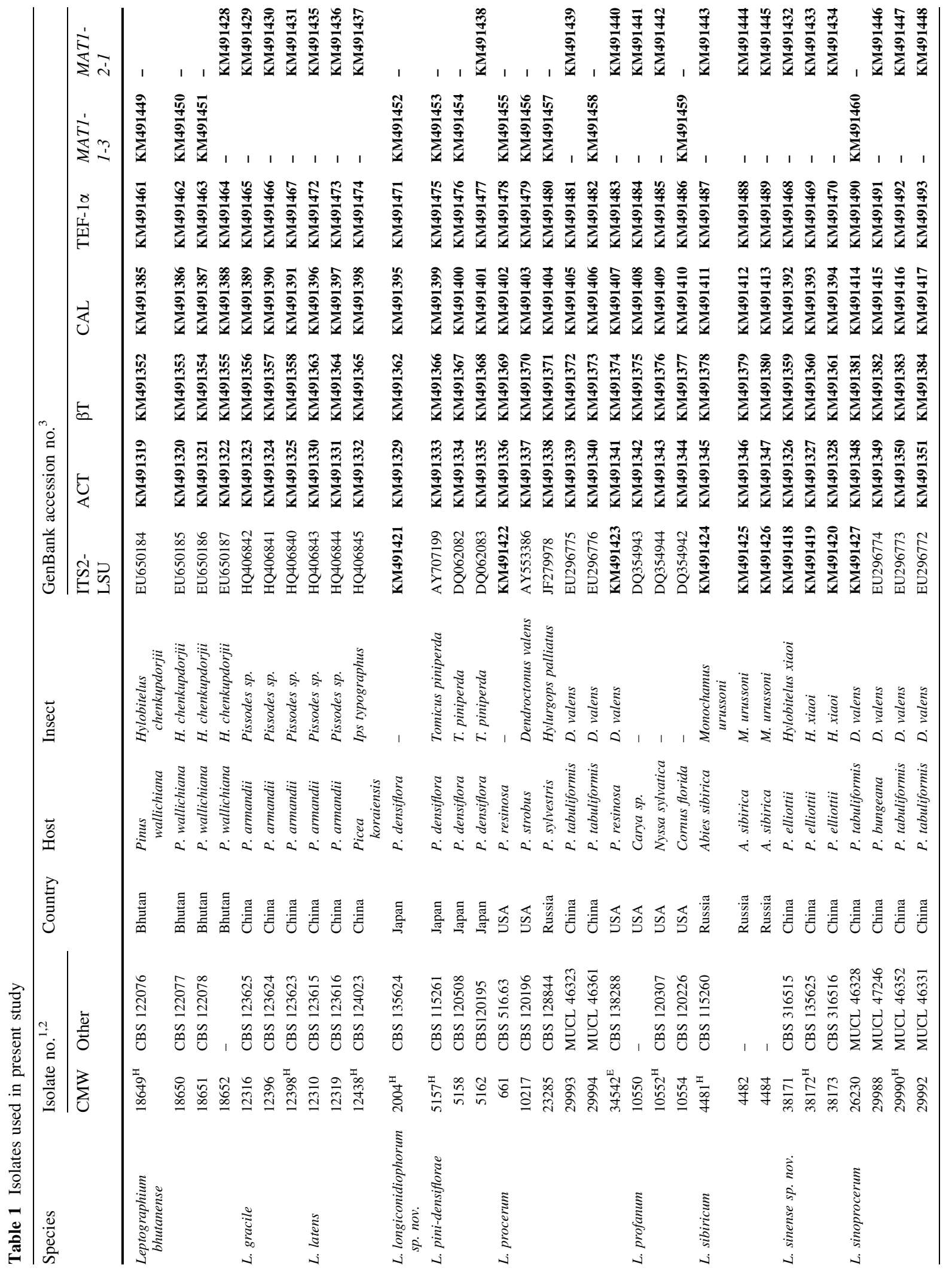




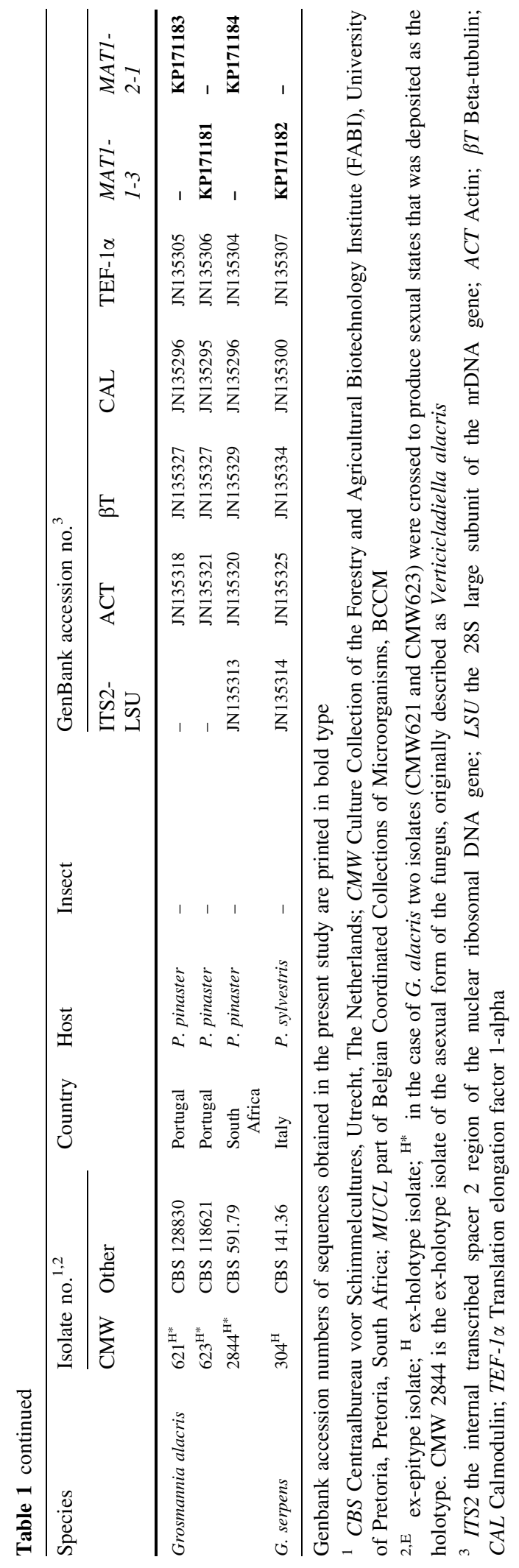

the ex-type isolate of each species in the L. procerum complex (Table 1) were compared with those of 58 other species in Leptographium s. $l$. obtained from Genbank to show the placement of the complex within the genus. Sequences of Fragosphaeria purpurea and $F$. reniformis were selected as outgroup taxa. A smaller dataset of ITS2-LSU sequences consisting 35 sequences for the species in the $L$. procerum complex (Table 1), was also compiled for use in the combined analyses.

Four protein coding gene regions (ACT, $\beta \mathrm{T}, \mathrm{CAL}$ and TEF- $1 \alpha$ ) in 35 isolates (Table 1) were sequenced for the delineation of closely related species in the $L$. procerum complex. These four data sets were included together with the ITS2-LSU data sub-set in the combined analyses. In the single gene and the combined datasets, sequences of G. alacris (CMW 2844, ex-type) and G. serpens (CMW 304, ex-type) from the study of Duong et al. (2012) were used as outgroup taxa.

The datasets for the two mating type gene regions (MAT1-1-3 and MAT1-2-1) consisted of varying numbers of sequences, depending on the mating type of the respective isolates (Table 1). Fourteen isolates were included in the MAT1-1-3 dataset, with sequences of G. alacris (CMW 623) and G. serpens (CMW 304) as outgroups (Duong et al. 2012). In the MAT1-2-1 dataset, sequences of 23 isolates were included (Table 1). In this case two isolates of $G$. alacris (CMW 621 and CMW 2844) were used as outgroup taxa, since no MAT1-2-1 sequences were available for G. serpens.

Because intron and exon composition of some protein coding genes vary between species and species complexes in Leptographium s. $l$. (De Beer and Wingfield 2013), it was important to consider the presence of introns in all sequences when alignments were made. To aid with the identification and appropriate alignment of introns, complete maps of the coding regions and introns of the four protein coding genes (Online Resources 1-4) were compiled based on the whole genome sequence of Grosmannia clavigera (kw1407; National Center for Biotechnology Information (NCBI), Genome PID: 39837) (DiGuistini et al. 2011). Alignments of the respective datasets were conducted using the online version of MAFFT 6.0 (Katoh et al. 2002). Alignments were checked manually in MEGA 5.1 (Tamura et al. 2011) and compared with the G. clavigera gene maps to ensure 
introns and exons were aligned appropriately. In this process, amino acid sequences of the exons were also considered using MEGA 5.1. No manual modifications were necessary.

Three methods of phylogenetic analyses were applied to all datasets. These included maximum parsimony (MP), maximum likelihood (ML) and Bayesian inference (BI). Before the analyses of the combined dataset, a partition homogeneity test (PHT) was conducted using PAUP* 4.0b10 (Swofford 2003) to examine the congruence of five gene regions.

MP analyses were executed in PAUP* $4.0 \mathrm{~b} 10$ (Swofford 2003) with heuristic searches of 1,000 replicates, tree bisection and reconnection (TBR) branch swapping options and excluding gaps. To determine the confidence of branch nodes, 1,000 repetitions of bootstrap were conducted. Tree length (TL), consistency index (CI), retention index (RI) and homoplasy index (HI) and rescaled consistency index $(\mathrm{RC})$ were recorded after generating the trees.

ML analyses were performed using the online version of PhyML 3.0 (Guindon et al. 2010). For these analyses the most appropriate substitution models were selected using jModelTest 2.1.1 (Posada 2008), and Nearest-Neighbor-Interchange (NNI) branch swapping were used. Confidence for nodes was determined by using 1,000 bootstrap replicates. Gaps were excluded.

BI analyses were conducted in MrBayes 3.2 (Ronquist et al. 2012) utilizing a Markov chain Monte Carlo (MCMC) method. The most appropriate evolutionary models were determined with jModelTest 2.1.1 as for ML analyses. Four independent Monte Carlo Markov chains were simultaneously run from a random starting tree for 5 million generations. Trees were sampled every 100 generations. Burn-in values were determined in Tracer 1.4 (Rambaut and Drummond 2007). Trees sampled in the burn-in phase were discarded and posterior probabilities were calculated from all the remaining trees.

Morphology, growth and mating studies

For microscope examination, isolates were inoculated on $2 \%$ water agar (WA, $20 \mathrm{~g}$ Difco agar and 1,000 ml deionized water) adjacent to sterilized pine twigs on the agar surface, and incubated at $25^{\circ} \mathrm{C}$ for $3-4$ weeks (Duong et al. 2012). Fruiting structures on pine twigs were transferred with a needle to microscope slides and mounted in water. Culture characteristics were studied on Oatmeal agar (OA, $30 \mathrm{~g}$ oatmeal, $20 \mathrm{~g}$ Difco Bacto ${ }^{\mathrm{TM}}$ malt extract, from Becton, Dickinson \& Company, and 1,000 $\mathrm{ml}$ deionized water), after incubation at $25{ }^{\circ} \mathrm{C}$ for $10-14$ days. Descriptions of morphology and classifications were based on criteria recommended by Jacobs and Wingfield (2001), and colours were based on the charts of Rayner (1970).

In order to determine optimal temperatures for growth in culture, two isolates per species, including ex-type isolates, were selected. Disks of agar were cut from the actively growing margins of 5-day-old colonies of isolates with a sterile $5 \mathrm{~mm}$ cork borer and transferred to the centers of $90 \mathrm{~mm}$ plates of MEA. Three replicates were prepared for each isolate and incubated in the dark at 5-35 ${ }^{\circ} \mathrm{C}$ at $5{ }^{\circ} \mathrm{C}$ intervals. Average diameters of each colony were measured once every 2 days until the mycelial growth reached the edges of the plates.

The mating type of each isolate was determined based on the results of the mating type PCR reactions described above. Isolates of opposite mating type of the same species were paired with each other in all possible combinations. These pairings were done on water agar with sterilized pieces of pine wood using the technique described by Grobbelaar et al. (2010), and incubated for $3-4$ months at $25^{\circ} \mathrm{C}$. Interspecific crosses were also performed using isolates of four morphologically indistinguishable species (L. bhutanense, L. sinoprocerum, L. gracile and L. latens). The crosses were inspected once a week for the presence of ascomata.

\section{Results}

DNA sequencing and phylogenetic analyses

A summary of the most important parameters applied in, as well as outcomes of, the phylogenetic analyses are presented in Table 2. The trees resulting from ML, MP and BI analyses of the Leptographium s. l. data, resulted in the species in the $L$. procerum complex always grouping together, although without significant statistical support (Online Resource 5). The complex grouped between the Grosmannia olivacea and Grosmannia serpens complexes. Tree topologies obtained from ITS2-LSU analyses were not able to separate all the species within the complex from each other. In all the ITS2-LSU trees $L$. procerum, $L$. sinoprocerum, L. bhutanense, L. gracile, L. latens, 
Table 2 Parameters used and outcomes of all phylogenetic analyses in the present study

\begin{tabular}{|c|c|c|c|c|c|c|c|c|c|}
\hline & & ITS2-LSU & ACT & $\beta \mathrm{T}$ & CAL & TEF-1 $\alpha$ & Combined & MAT1-1-3 & MAT1-2-1 \\
\hline \multirow[t]{6}{*}{ Alignments } & Exons(introns) & Not applicable & $5(5) 6$ & $\begin{array}{l}2(2) 3(3) \\
\quad 4(4) 5(-) 6\end{array}$ & $\begin{array}{r}3(3) 4(4) \\
5(-) 6\end{array}$ & $3(3) 4(4) 5$ & - & $1,2 / 1$ & $2,3 / 2$ \\
\hline & Number of taxa & 70 & 35 & 35 & 35 & 35 & 35 & 14 & 23 \\
\hline & Total & 612 & 814 & 484 & 537 & 792 & 3,232 & 379 & 205 \\
\hline & Constant & 419 & 707 & 363 & 379 & 506 & 2,532 & 257 & 147 \\
\hline & Uninformative & 62 & 1 & 5 & 3 & 8 & 20 & 6 & 5 \\
\hline & Informative & 133 & 106 & 116 & 155 & 278 & 680 & 116 & 53 \\
\hline \multirow[t]{6}{*}{ MP } & Tree number & 1,000 & 1 & 1 & 2 & 1 & 1 & 2 & 1 \\
\hline & Tree length & 398 & 121 & 143 & 186 & 368 & 847 & 128 & 62 \\
\hline & CI & 0.585 & 0.967 & 0.944 & 0.919 & 0.894 & 0.920 & 0.984 & 0.919 \\
\hline & RI & 0.891 & 0.990 & 0.981 & 0.974 & 0.962 & 0.973 & 0.988 & 0.959 \\
\hline & $\mathrm{RC}$ & 0.521 & 0.958 & 0.926 & 0.895 & 0.860 & 0.895 & 0.973 & 0.881 \\
\hline & HI & 0.415 & 0.033 & 0.056 & 0.081 & 0.106 & 0.080 & 0.016 & 0.081 \\
\hline Model tests & Subst. models & $\mathrm{GTR}+\mathrm{I}+\mathrm{G}$ & $\mathrm{GTR}+\mathrm{G}$ & $\mathrm{GTR}+\mathrm{G}$ & $\mathrm{GTR}+\mathrm{G}$ & $\mathrm{GTR}+\mathrm{G}$ & $\mathrm{GTR}+\mathrm{G}$ & K80 & $\mathrm{HKY}+\mathrm{I}$ \\
\hline \multirow[t]{2}{*}{ ML } & P-inv & 0.511 & - & - & - & - & - & - & 0.341 \\
\hline & Gamma & 0.686 & 0.257 & 0.550 & 0.508 & 0.683 & 0.341 & - & - \\
\hline BI & Burn-in & 50 & 40 & 30 & 30 & 30 & 30 & 20 & 20 \\
\hline
\end{tabular}

$M P$ maximum parsimony, $M L$ maximum likelihood, BI Bayesian inference, Uninformative Number of parsimony-uninformative characters, Informative Number of parsimony-informative characters, $C I$ consistency index, $R I$ retention index, $R C$ rescaled consistency index, HI homoplasy index, Subst. model substitution models in phylogeny, P-inv proportion of invariable sites, Gamma Gamma distribution shape parameter

grouped with the four unidentified isolates from China and Japan. Leptographium profanum grouped within the main lineage containing the latter seven species, but differed by $1 \mathrm{bp}$ from the other species in the lineage (Online Resource 5). The only two species that were distinct, were $L$. pini-densiflorae and $L$. sibiricum that formed an unsupported sub-lineage within the complex.

The intron/exon composition in the amplified ACT gene region of all species in the complex (Table 2) corresponded with that of $G$. clavigera (Online Resource 1). Sequences for the ACT dataset distinguished between all the species in the complex, apart from $L$. sinoprocerum, $L$. gracile and L. latens for which all isolates had identical sequences (Online Resource 6). The single isolate from Japan and the isolates obtained from China in the present study (Table 1), formed a well-supported monophyletic lineage distinct from all the other species in the complex, but differed in $1 \mathrm{bp}$ from each other in exon 5 (Online Resource 7). They were thus respectively labeled as Taxon 1 and Taxon 2 .

In the alignment of the $\beta \mathrm{T}$ gene region, intron 5 , which is not present in G. clavigera (Online Resource 2), but is found in some other Leptographium spp. (De
Beer and Wingfield 2013), was lacking in all species of the L. procerum complex (Table 2). Analyses of the $\beta T$ region (Online Resource 6) distinguished between most species in the complex, apart from L. sinoprocerum, L. gracile and L. latens that had identical sequences. Sequences for this gene region also failed to distinguish between Taxa 1 and 2 from China and Japan.

Within the sequence data for the CAL region, the intron/exon composition (Table 2) corresponded with that of G. clavigera (Online Resource 3) with intron 5 being absent while it is found in some other species complexes in the Ophiostomatales (De Beer, unpublished). The phylogenies obtained from this data set showed differences between most species in the complex, including Taxa 1 and 2, but in this case $L$. bhutanense and L. sinoprocerum had identical sequences, as did L. gracile and L. latens (Online Resource 6).

The intron/exon composition of the TEF- $1 \alpha$ gene of species in the L. procerum complex (Table 2) did not correspond with that of G. clavigera, which lacks intron 4 (Online Resource 4). Phylogenetic analyses of this gene resolved all the species in the complex, apart 
from $L$. gracile and L. latens which had identical sequences (Online Resource 6).

The partition homogeneity test (PHT) of the combined dataset (ITS2-LSU, ACT, $\beta$ T, CAL and TEF- $1 \alpha$ ) gave a $P$ value of 0.648 , indicating that data of the five gene regions could be combined. The MP, ML and BI analyses of the combined dataset provided trees with similar topologies and no conflicts (Fig. 1). Six of the known species (L. bhutanense, L. procerum, L. profanum, L. pini-densiflorae, $L$. sibiricum and L. sinoprocerum) in the $L$. procerum complex were well-defined. Similarly, the isolate from Japan (Taxon 1) and those from China (Taxon 2) formed distinct lineages. Two of the previously known species, L. gracile and L. latens, had identical sequences in all the gene regions (Online Resources 5 and 6). The ten taxa grouped in three wellsupported major lineages (Fig. 1), labeled as groups A, B, and C. Group A included L. bhutanense, $L$. sinoprocerum, L. gracile, L. latens, Taxon 1 and Taxon 2. Group B included L. procerum and $L$. profanum, and Group C L. pini-densiflorae and L. sibiricum.

The MAT1-1-3 data set included 14 isolates (Taxon 1, L. bhutanense, L. procerum, L. profanum, L. pinidensiflorae and $L$. sinoprocerum), representing six species of the L. procerum complex. In the resulting phylogeny (Fig. 2), four of the six species could be distinguished, but L. bhutanense and L. sinoprocerum had identical sequences.

The phylogenetic analyses of aligned data set of the MAT1-2-1 gene (Fig. 2) could only distinguish between $L$. procerum, $L$. profanum, $L$. pini-densiflorae and $L$. sibiricum, while $L$. bhutanense, $L$. sinoprocerum, $L$. gracile, L. latens and Taxon 2 all had identical sequences.

Morphology, growth in culture and mating studies

All five groups representing the Chinese isolates and the Japanese isolate formed olivaceous leptographium-like asexual states similar to L. bhutanense and L. sinoprocerum. Moreover, L. pini-densiflorae and L. sibiricum could be distinguished from the other species with colorless mycelium on both OA and MEA. Morphological differences between Taxa 1 and 2 and the other species are discussed in the Notes provided for the new species descriptions in the "Taxonomy" section.

The optimal growth temperature for most isolates was $25^{\circ} \mathrm{C}$, with the only exception being L. bhutanense that grew best at $20{ }^{\circ} \mathrm{C}$ and L. pini-densiflorae and L. sibiricum which grew best at $30{ }^{\circ} \mathrm{C}$. Four species (L. bhutanense, L. latens, L. gracile and $L$. sinoprocerum) were extremely slow growing or had no growth at 5 or $30{ }^{\circ} \mathrm{C}$. None of the isolates in the study grew below $5{ }^{\circ} \mathrm{C}$, or at $35^{\circ} \mathrm{C}$. None of the crosses between isolates in the $L$. procerum complex gave rise to ascomata.

\section{Taxonomy}

Multilocus phylogenetic analyses of 33 isolates revealed nine well-supported lineages in the $L$. procerum complex. Six of these lineages represented previously described species. These included L. procerum, for which an epitype is designated below. One isolate from Japan, previously identified as L. procerum based on morphology, formed a distinct lineage representing a new species (Taxon 1), as did the isolates collected from H. xiaoi in China (Taxon 2).

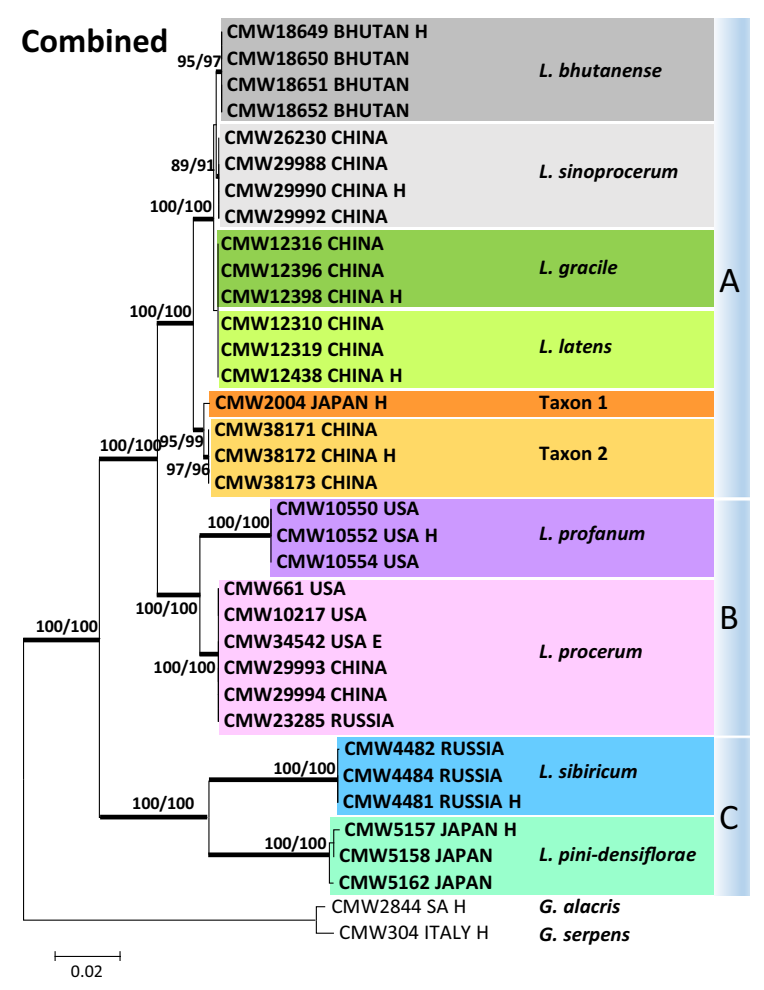

Fig. 1 ML trees of the Leptographium procerum complex generated from the DNA sequences of the ribosomal ITS2-LSU regions, combined with those of four protein-coding gene regions, including ACT, $\beta$ T, CAL and TEF $1-\alpha$. Bold branches indicate posterior probabilities values $\geq 0.95$. Bootstrap values $\geq 75 \%$ are recorded at nodes as ML/MP. H ex-holotype isolates, E ex-epitype isolate 
These two taxa are described here as novel species. The ninth lineage consisted of isolates of both $L$. gracile and L. latens, including those linked to the holotypes of the two species. Isolates of these two species had identical sequences in all six gene regions and they are reduced to synonymy. Based on the recommendations of De Beer and Wingfield (2013), all species in the complex are treated in the genus Leptographium sensu lato.

Leptographium procerum (W.B. Kendr.) M.J. Wingf., Trans. Br. Mycol. Soc. 85: 92 (1985). MB 105454

$\equiv$ Verticicladiella procera W.B. Kendr., Can. J. Bot. 40: 783 (1962). (Basionym) MB 340902

Sexual state not observed. Asexual state, conidiophores occurring singly or in groups of up to three, macronematous, mononematous, erect, arising directly from the mycelium, (150-) 245-570 (-760) $\mu \mathrm{m}$ long. Rhizoids present. Stipes olivaceous, 3-10 septa, not constricted at septa, (125-) 206-496 (-690) $\mu \mathrm{m}$ long. Apical cells not swollen at apex, 3-15 $\mu$ m wide. Basal cells not swollen at apex. Conidiogenous apparatus (25-) 39.4-75 (-90) $\mu \mathrm{m}$ long, excluding the conidial mass, with 2 to 5 series of cylindrical branches. Primary branches light olivaceous, smooth, cylindrical, aseptate, arrangement of primary branches Type B-more than two branches, (11-) 16-22 (-34) $\times(3-)$ 4-5 (-7) $\mu \mathrm{m}$. Secondary branches light olivaceous, aseptate, (8-) 11-12 (-15) × (2-) 3-4 (-7) $\mu \mathrm{m}$. Tertiary branches hyaline, aseptate, (7-) 7-13 $(-14) \times 2-6 \mu \mathrm{m}$. Quaternary branches aseptate, (7-) 8-12 $(-13) \times 2-5 \mu \mathrm{m}$. Conidiogenous cells discrete, 2-4 per branch, cylindrical, tapering slightly at apex, (11-) 15-18 (-22) $\times 1-2 \mu \mathrm{m}$. Conidia hyaline, aseptate, obovoid to broadly ellipsoid with truncate bases and rounded apices, $3-5 \times 1-3 \mu \mathrm{m}$. Colonies on $3 \%$ OA flat, hyaline at the beginning, then becoming light olivaceous to dark olivaceous. Hyphae submerged in agar with no aerial mycelium, concentric rings observed. Colony margin smooth or slightly effuse. Conidiophores forms abundantly in clusters on OA. Colonies on $2 \%$ MEA flat, with optimal growth at $25{ }^{\circ} \mathrm{C}$, reaching $25 \mathrm{~mm}$ in diam. in 7 days. No growth below $10{ }^{\circ} \mathrm{C}$ nor above $30{ }^{\circ} \mathrm{C}$.

Mating system Heterothallic based on presence of MAT genes, but no sexual states were obtained in crosses.

Type material Holotype CANADA, Quebec, Baie St. Paul, from Pinus banksiana stump, Sep 1959, coll. W. B. Kendrick, DAOM 63700. Paratypes USA, New York state, Montgomery Co., from interior of roots with resinous lesions of Pinus resinosa, Feb 1959, coll. D. S. Welch, DAOM 62093; Newfield, DAOM 62094; CANADA, Columbia Co., DAOM 62095; Stockton, Chatauqua Co., DAOM 62096; Ontario, Sudbury, from Pinus strobus heart rot, Sep 1952, S. N. Linzon, DAOM 33940. SWEDEN, Södermanland, Järna, from galleries of Pissodes pini on Pinus sp., Aug 1959, coll. A. Mathiesen-Käärik, DAOM 63686.

Epitype (designated here): USA, Maine, Massabesic Experimental Forest, from Dendroctonus valens gallery on Pinus resinosa, Nov 2009, coll. M. J. Wingfield. PREM 61058 (herbarium specimen of dried culture); CMW 34542 = CBS 138288 (ex-epitype culture), MBT 198257.

Additional isolates examined USA, Vermont, from Pinus strobus, 2000, coll. K. Jacobs, CMW 10217.
Fig. 2 ML trees of the Leptographium procerum complex generated from DNA sequences of the MAT1-1-3 and MAT1-2-1 gene regions. Bold branches indicate posterior probabilities values $\geq 0.95$. * bootstrap values $<75 \%$. $\mathrm{H}$ ex-holotype isolates, E ex-epitype isolate

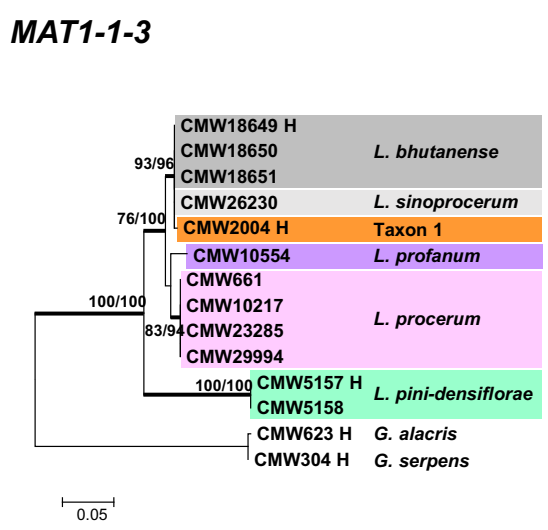


RUSSIA, Lisino-Corpus, from Pinus sylvestris, associated with Hylurgops palliatus, 2012, coll. R. Linnakoski, CMW $23285=$ CBS 128844. CHINA, from Pinus tabuliformis, sapwood underneath gallery of Dendroctonus valens, 2004, coll. Q. Lu., CMW $29993=$ MUCL 46323; CMW $29994=$ MUCL 46361.

Hosts/Substrate Abies fraseri, A. grandis, Picea abies*, Pinus banksiana, P. bungeana, P. clausa, P. contorta, P. densiflora, P. echinata, P. elliottii, $P$. monticola, $P$. nigra, $P$. ponderosa, $P$. radiata*, P. resinosa*, $P$. strobus $*$, P. sylvestris ${ }^{*}, P$. tabuliformis*, P. taeda, $P$. virginiana, Pseudotsuga menziesii.

Insect vectors Dendroctonus frontalis, D. terebrans, D. valens*, Hylastes ater*, H. opacus*, Hylobius abietis*, H. pales, H. radicis, Hylurgops palliatus*, Hylurgus ligniperda, Ips typographus, I. sexdentatus*, Pachylobius picivorus, Pissodes approximatus, Pissodes castaneus*, P. nemorensis, P. pini*, P. piniphilus $^{*}$, Pityogenes sp., Tomicus piniperda, Tetropium fuscum*, Xyleborus sp.

Known distribution North America (Canada and USA*), Europe (Sweden, Poland*, UK, France and Russia*), Asia (Japan and China*), South Africa, and New Zealand*.

* Hosts, vectors and origin from studies where the identity of $L$. procerum was confirmed based on DNA sequences (Jacobs et al. 2004; Jankowiak 2012; Jankowiak and Bilański 2013a, b, c; Jankowiak and Kolařík 2010; Kim et al. 2005; Lu et al. 2008, 2009a, b; Linnakoski et al. 2012; and from the present study). All unmarked hosts and vectors were listed by Jacobs and Wingfield (2001), but identifications were based on morphology only.

Notes Leptographium procerum was first described as Verticicladiella procera. The genus Verticicladiella was subsequently reduced to synonymy with Leptographium based on similarities of conidial development as revealed by scanning electron microscopy, and a new combination for this species in Leptographium was thus provided (Wingfield 1985). The holotype of $L$. procerum originates from $P$. resinosa in Quebec, Canada, while four of the paratype specimens are from Pinus resinosa from various locations in New York, USA. The remaining two paratypes originated from Pinus strobus in Ontario and pine in Sweden respectively (Kendrick 1962). There are no living cultures of the holotype and paratypes that could be used for DNA sequencing. During recent surveys of fungal associates of Dendroctonus valens infesting $P$. resinosa in the Northeastern USA (Taerum et al. 2013), many fresh isolates of $L$. procerum were obtained. One of these, CMW 34542 from P. strobus in Maine, corresponds with the original descriptions based on morphology and with other L. procerum isolates based on DNA sequences and it is consequently designated here as the epitype for the species.

\section{Taxon 1}

Leptographium longiconidiophorum M.L. Yin, Z.W. de Beer \& M.J. Wingf., sp. nov. Fig. 3

Mycobank MB 805970

Etymology Name reflects the exceptionally long conidiophores that distinguish it from all other species in the L. procerum complex.

Sexual state not observed. Asexual state, conidiophores occurring singly or in groups of up to 10 , macronematous, mononematous, erect, arising directly from the mycelium, (1,030-) 1,580-2,150 (-2,460) $\mu \mathrm{m}$ long. Rhizoids present. Stipes dark olivaceous, 2-14 septa, not constricted at septa, (979-) 1,403-1,980 $(-2,320) \mu \mathrm{m}$ long. Apical cells occasionally swollen at apex, (6-) 9-14 (-16) $\mu \mathrm{m}$ wide. Basal cells occasionally swollen at apex, (9-) 11-17 $(-20) \mu \mathrm{m}$ wide. Conidiogenous apparatus (60-) 110-125 (-142) $\mu \mathrm{m}$ long, excluding the conidial mass, with multiple series of cylindrical branches. Primary branches olivaceous, smooth, cylindrical, not swollen at apex, aseptate, arrangement of primary branches was Type A-only two branches, (25-) 30-35 (-42) × (4.9-) 5.8-6.9 $(-7.2) \mu \mathrm{m}$. Secondary branches light olivaceous, frequently swollen at apex, aseptate, (12-) 16-20 $(-27) \times(3.9-) 4.3-4.9(-5.6) \mu \mathrm{m}$. Tertiary branches light olivaceous, aseptate, (9-) 13-17 (-20) × (3.5-) 4.1-4.7 (-5.0) $\mu \mathrm{m}$. Quaternary branches light olivaceous to hyaline, aseptate, (5-) 9-15 (-17) $\times(1.6-)$ 2.1-2.7 (-3.2) $\mu \mathrm{m}$. Conidiogenous cells discrete, hyaline, 2-3 per branch, aseptate, cylindrical, tapering slightly at the apex, (16-) 19-22 (-25) $\times(1.3-)$ 1.6-1.9 (-2.1) $\mu \mathrm{m}$. Conidia hyaline, aseptate, elliptical, (2.7-) 3.5-4.8 (-5.1) × (1.6-) 1.9-2.2 (-2.4) $\mu \mathrm{m}$. Colonies on $3 \%$ OA flat, hyaline at the beginning, then becoming light olivaceous to dark olivaceous. Hyphae superficial on agar with olivaceous aerial mycelium, no concentric rings observed. Colony margin smooth. Conidiophores forms abundantly in clusters on OA. Colonies on $2 \%$ MEA flat, with 
optimal growth at $25^{\circ} \mathrm{C}$, reaching $30.5 \mathrm{~mm}$ in diam. in 7 days. No growth below $10{ }^{\circ} \mathrm{C}$ and at $35^{\circ} \mathrm{C}$ or above.

Mating system Heterothallic based on the presence of MAT genes, but no sexual state was found in laboratory crosses.

Type material Holotype JAPAN, Kofu, from Pinus densiflora, 2002, coll. M. J. Wingfield, PREM 60872 (herbarium specimen of dried culture); CMW $2004=$ CBS 135624 (ex-holotype culture).

\section{Hosts/Substrate Pinus densiflora.}

Known distribution Japan.

Notes Leptographium longiconidiophorum is phylogenetically closely related to but clearly distinct from L. sinense (Fig. 1 and Online Resource 6), differing from that species in $1 \mathrm{bp}$ in ACT, $3 \mathrm{bp}$ in CAL, and 5 bp in TEF- $1 \alpha$ (Online Resource 7). This fungus can be distinguished from all other species in the complex, including $L$. sinense, by its conidiophores that are much longer (almost double the length) than those of the other species. Furthermore, its conidiophores are often produced in clusters distributed over the medium and do not form concentric rings on OA such as those of $L$. sinense. Despite the fact that only one isolate of this species was available for study, we describe it here based on the clear phylogenetic and morphological differences with other species in the complex.

\section{Taxon 2}

Leptographium sinense M.L. Yin, Z.W. de Beer \& M.J. Wingf., sp. nov. Fig. 4

Mycobank MB 805971

Etymology Name refers to China where it was first collected.

Sexual state not observed. Asexual state, conidiophores occurring singly, macronematous, mononematous, erect, arising directly from the mycelium, (608-) 753-893 (-1,039) $\mu \mathrm{m}$ long. Rhizoids present. Stipes dark brown, 3-9 septa, not constricted at the septa, (544-) 608-770 (-936) $\mu \mathrm{m}$ long. Apical cells occasionally swollen at the apex, (7-) 10-13 (-15) $\mu \mathrm{m}$ wide. Basal cells occasionally swollen at apex, (9-) 11-17 (-20) $\mu \mathrm{m}$ wide. Conidiogenous apparatus (120-) 144-175 (-196) $\mu \mathrm{m}$ long, excluding the conidial mass, with multiple series of cylindrical branches. Primary branches brown, smooth, cylindrical, not swollen at apex, aseptate, arrangement of primary
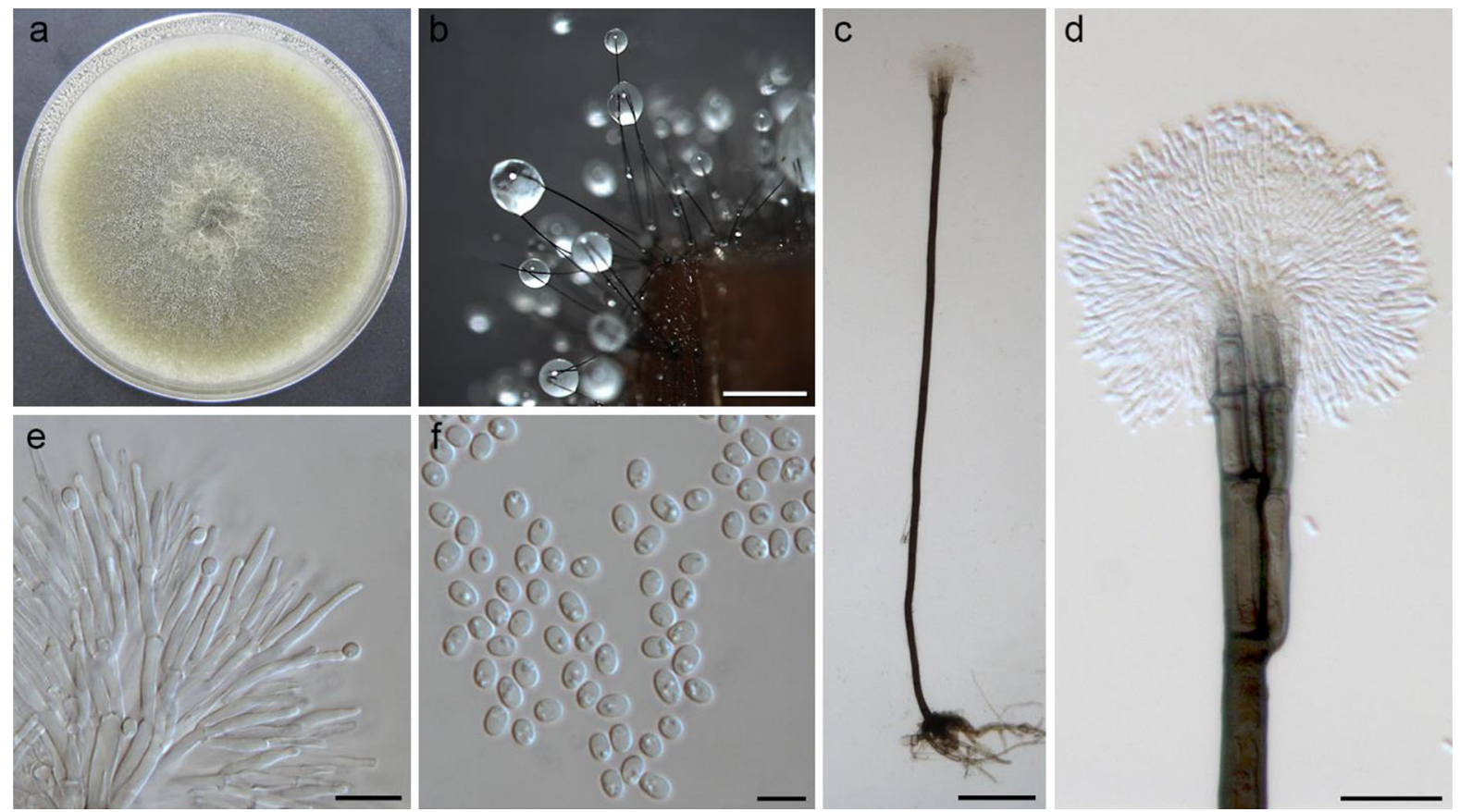

Fig. 3 Morphological characters of Leptographium longiconidiophorum (CMW2004) a Fourteen days old culture on $90 \mathrm{~mm}$ $\mathrm{OA}$; b mononematous asexual morph on wood tissue on WA; c conidiophore; $\mathbf{d}$ conidiogenous apparatus; e conidiogenous cells; f conidia. Scale bars $\mathrm{b}=500 \mu \mathrm{m}, \quad \mathrm{c}=100 \mu \mathrm{m}$, $\mathrm{d}=20 \mu \mathrm{m}, \mathrm{e}=10 \mu \mathrm{m}, \mathrm{f}=5 \mu \mathrm{m}$ 

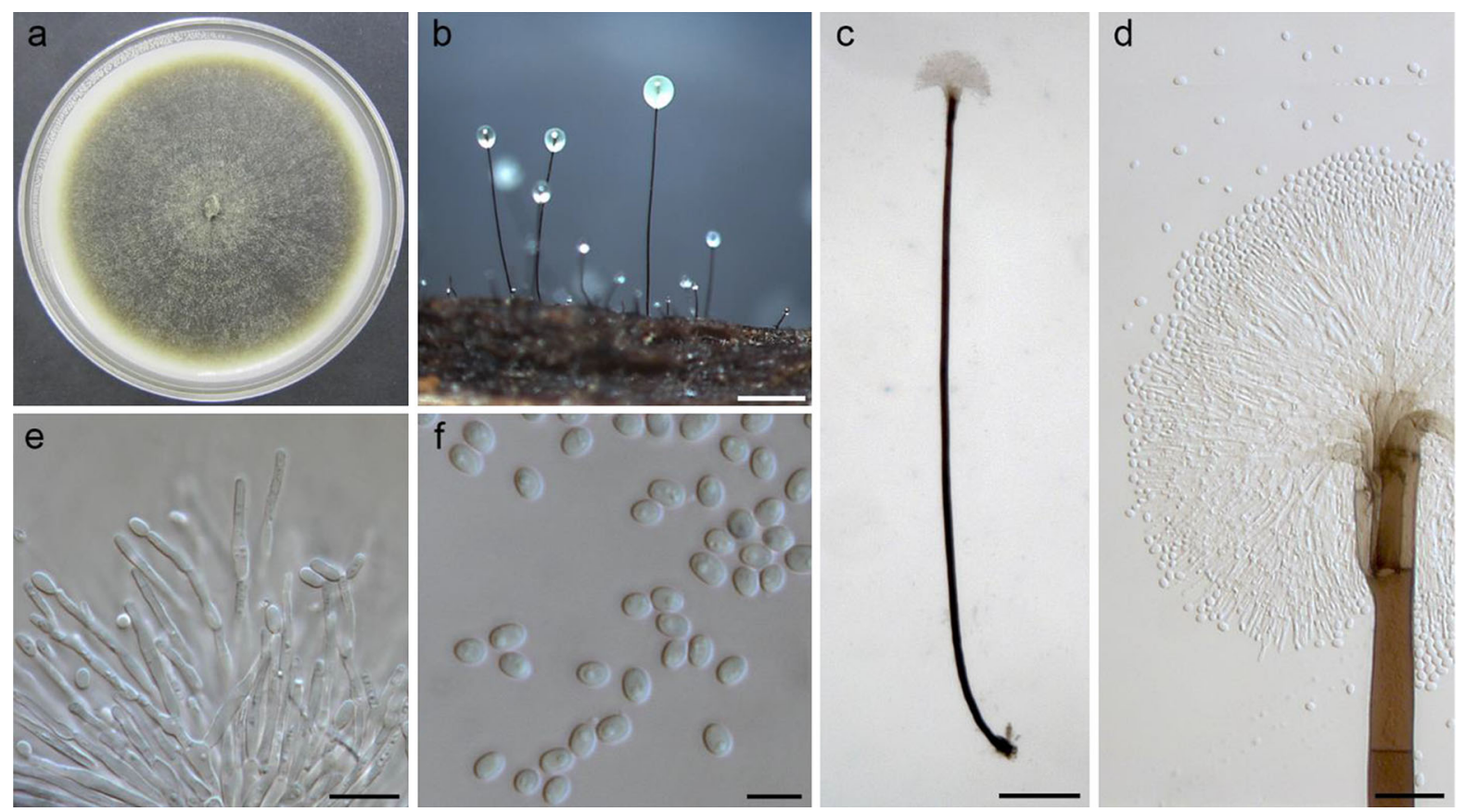

Fig. 4 Morphological characters of Leptographium sinense (CMW38172) a Fourteen days old culture on $90 \mathrm{~mm}$ OA; b mononematous asexual morph on wood tissue on WA;

branches was Type A - only two branches, (19-) 21-28 $(-36) \times(4.5-)$ 5.5-8.9 (-9.7) $\mu \mathrm{m}$. Secondary branches light brown, frequently swollen at apex, aseptate, (10-) 15-24 (-30) × (2.9-) 4.3-5.4 (-6.6) $\mu \mathrm{m}$. Tertiary branches light brown to hyaline, aseptate, (10-) 12-18 $(-21) \times(2.9-) 3.4-4.1(-4.9) \mu \mathrm{m}$. Quaternary branches hyaline, aseptate, (5-) 8-12 (-16) × (1.7-) 2.0-2.5 $(-3.3) \mu \mathrm{m}$. Conidiogenous cells discrete, hyaline, 2-3 per branch, aseptate, cylindrical, tapering slightly at the apex, (10-) 12-16 (-20) × (1.2-) 1.6-2.2 (-2.5) $\mu \mathrm{m}$. Conidia hyaline, aseptate, elliptical to round, (2.9-) 3.4-4.1 (-4.9) × (1.9-) 2.4-2.7 (-3.0) $\mu \mathrm{m}$. Colonies on $3 \%$ OA flat, hyaline at the beginning, then becoming light olivaceous to dark olivaceous. Hyphae superficial on the agar with olivaceous aerial mycelium, multiple concentric rings observed. Colony margin smooth. Conidiophores forms abundantly in clusters on OA. Colonies on $2 \%$ MEA flat, with optimal growth at $25{ }^{\circ} \mathrm{C}$. No growth below $10{ }^{\circ} \mathrm{C}$ and at $35^{\circ} \mathrm{C}$ or above.

Mating system Heterothallic based on the presence of MAT genes but a sexual state was not produced in crosses.

Type material Holotype CHINA, Jiangxi province, from Pinus elliottii, 2010, coll. X.D. Zhou, PREM c conidiophore; $\mathbf{d}$ conidiogenous apparatus; e conidiogenous cells; f conidia. Scale bars $\mathrm{b}=300 \mu \mathrm{m}, \quad \mathrm{c}=100 \mu \mathrm{m}$, $\mathrm{d}=20 \mu \mathrm{m}, \mathrm{e}=10 \mu \mathrm{m}, \mathrm{f}=5 \mu \mathrm{m}$

60873 (herbarium specimen of dried culture), CMW 38172 = CBS 135625 (ex-holotype culture).

Additional isolates examined CHINA, Jiangxi province, from Pinus elliottii, 2010, coll. M. Yin, R. Chang \& X.D. Zhou, CMW $38171=$ CBS 316515; CMW 38173 = CBS 316516.

\section{Hosts/Substrate Pinus elliottii.}

Insect vectors Hylobitelus xiaoi

Known distribution Jiangxi, China.

Notes Leptographium sinense grouped close to, but distinct from $L$. longiconidiophorum in phylogenetic analyses (Fig. 1 and Online Resource 6), and can clearly be separated from that species based on sequences in three gene regions (Online Resource 7). Morphologically, it differs from L. longiconidiophorum with its shorter and darker conidiophores occurring singly and in multiple concentric rings on OA.

Leptographium gracile D. Paciura, Z.W. de Beer \& M.J. Wingf., Persoonia 25:103 (2010). MB 516736

= Leptographium latens D. Paciura, Z.W. de Beer \& M.J. Wingf., Persoonia 25:104 (2010). MB 516737

Type material For L. gracile CHINA, Yunnan Province, Midu, from Pinus armandii infested by 
Pissodes sp., July 2001, coll. X.D. Zhou \& Z.W. de Beer, holotype PREM 59995 (herbarium specimen of dried culture), CMW $12398=$ CBS 123623 (exholotype culture); paratype PREM 59996 (herbarium specimen of dried culture), CMW $12396=\mathrm{CBS}$ 123624 (ex-paratype culture); Yunnan Province, Lijiang, from Pinus armandii, infested by Pissodes sp., July 2001, coll. X.D. Zhou \& Z.W. de Beer, paratype PREM 59997 (herbarium specimen of dried culture), CMW 12316 = CBS 123625 (ex-paratype culture). For L. latens CHINA, Yunnan Province, Midu, from Picea koraiensis infested by Ips typographus, July 2001, coll. X.D. Zhou \& Z.W. de Beer, holotype PREM 60007 (herbarium specimen of dried culture), CMW 12438 = CBS 124023 (ex-holotype culture); Yunnan Province, Lijiang, from Pinus armandii infested by Pissodes sp., July 2001, coll. X.D. Zhou \& Z.W. de Beer, paratype PREM 60008 (herbarium specimen of dried culture), CMW $12310=$ CBS 123615 (ex-paratype culture); Yunnan Province, Midu, from Pinus armandii infested by Pissodes sp., July 2001, coll. X.D. Zhou \& Z.W. de Beer, paratype PREM 60009 (herbarium specimen of dried culture), CMW 12319 = CBS 123616 (ex-paratype culture).

Notes Paciura et al. (2010) described L. gracile and L. latens, comparing the species based on sequences of three gene regions (ITS2-LSU, $\beta$-tubulin and TEF$1 \alpha$ ). They distinguished between the two species based on differences in the latter two gene regions and slightly longer conidia of L. latens. In the present study, seven gene regions were used for phylogenetic analyses and all the genes previously used to distinguish $L$. gracile and L. latens were resequenced together with the two closely related species, $L$. bhutanense and $L$. sinoprocerum. The results showed that $L$. gracile and L. latens had identical sequences in all gene regions (Fig. 1 and Online Resources 6 and 7), while $L$. bhutanense and $L$. sinoprocerum could be distinguished from them and from each other. We thus consider $L$. gracile to be a synonym of $L$. latens.

\section{Discussion}

In this study, the taxonomy of all species in the $L$. procerum complex was revised based on phylogenetic analyses of sequences for seven gene regions. Representative isolates of eight known species were included, as well as a collection of unidentified isolates from China, and an isolate from Japan previously thought to represent $L$. procerum. The isolates from the latter two countries were shown to represent novel taxa that were described as $L$. sinense and L. longiconidiophorum. Furthermore, an epitype was designated for $L$. procerum, and two species previously described from China ( $L$. gracile and $L$. latens) were shown to be conspecific. The L. procerum complex now includes nine well-defined species $(L$. bhutanense, L. gracile, L. longiconidiophorum, $L$. pini-densiflorae, L. procerum, L. profanum, L. sibiricum, $L$. sinense, and L. sinoprocerum) primarily occurring in association with bark beetles infesting pine trees. Sequences obtained for the mating type genes of these species suggest that they are all heterothallic.

Among the seven gene regions that were used in the phylogenetic analyses, TEF- $1 \alpha$ was the most variable and most informative region, distinguishing between all nine species in $L$. procerum complex as defined based on the combined analyses of five of the gene regions. The CAL gene region was also useful in delineating the species, but with slightly fewer variable sites than TEF- $1 \alpha$. In contrast, ITS2-LSU has the lowest number of variable sites and could distinguish only two species (L. pini-densiflorae and L. sibiricum) from all the other species that all had almost identical sequences for this region. The partial MAT genes were not useful in distinguishing between closely related species. Although the ITS region has been suggested as barcoding region for fungi (Schoch et al. 2012), our results suggest that the ITS2-LSU region would be useful only to place isolates in a particular complex in Leptographium s. $l$. and not to distinguish between species in that complex. We suggest that the TEF- $1 \alpha$ gene region should be considered as an additional barcoding gene for accurate species identification in this genus.

All isolates in the L. procerum complex included in this study had either one of the two MAT genes, suggesting that all species in the complex are heterothallic. This is consistent with the findings of Duong et al. (2013) who showed that $L$. procerum and $L$. profanum are heterothallic. We were, however, not able to induce a sexual state for any of the species in laboratory crosses. The fact that the sexual state has not been observed in nature and despite some intensive searching (Wingfield, unpublished), could be due to a cryptic nature or the absence of long-necked perithecia 
that are characteristic for the majority of Leptographium spp. for which sexual states are known (Jacobs and Wingfield 2001). This would be consistent with the fact that some species, e.g. G. clavigera (RobinsonJeffrey and Davidson 1968) and G. yunnanense (Yamaoka et al. 2008), are known to produce cleistothecial ascomata that are embedded in the woody substrate and thus not visible during routine inspections of bark beetle galleries.

The three major lineages making up the $L$. procerum complex as defined in this study corresponded to the geographical origin of the isolates. Group B (Fig. 1) included two species, $L$. procerum and $L$. profanum, and could be referred to as the North American-European lineage. Leptographium procerum was initially known only from North America (Canada and USA) (Kendrick 1962), subsequently it was found in other parts of the world, including Europe [e.g. UK (Wingfield and Gibbs 1991) and Poland (Jacobs and Wingfield 2001; Jankowiak and Bilański 2013a, b, c)], and Asia [e.g. Japan (Masuya et al. 1999) and more recently China (Lu et al. 2008)]. The species has also been found in association with introduced bark beetles on exotic pines in New Zealand (Wingfield and Marasas 1983) and South Africa (Zhou et al. 2001). This fungus has been reported on many different Pinus spp. on which its various and generally non-host specific vectors feed. Several recent studies suggest that $L$. procerum is the dominant associate of D. valens (Taerum et al. 2013), but the fungus is certainly not carried specifically by that beetle, as it has been isolated from various other bark beetles and weevils (Alexander et al. 1988; Jacobs and Wingfield 2001; Jankowiak and Bilański 2013a, b, c), most notably those that infest roots or root collars of trees. This explains why the fungus has often been associated with root diseases of trees, even though its role as pathogen has been questioned (Wingfield 1986; Wingfield et al. 1988; Jacobs and Wingfield 2001; Jankowiak 2006). More recently the suggestion has been made that $L$. procerum might be a soil fungus in pine forests that infests roots through wounds caused by insects (Jankowiak et al. 2012).

Leptographium profanum, also residing in the North American-European lineage (Group B), is the only species in the L. procerum complex that has been isolated from hardwood trees. It is known only from central Alabama (USA) where it was isolated from roots of Nyssa sylvatica, Cornus florida and a Carya sp. (Jacobs et al. 2006). Unlike other species in the complex, there is no evidence that $L$. profanum is associated with bark beetles. It remains uncertain whether it is a soil-inhabiting fungus, or carried by mites, or whether it might be associated with some undiscovered root-infesting insect species.

All seven species belonging to Groups A and C (Fig. 1) of the L. procerum complex are from conifers in Asia. Group A is the largest group and includes five species, L. bhutanense, L. gracile, L. sinoprocerum, $L$. sinense and L. longiconidiophorum, while Group C includes two species, $L$. pini-densiflorae and $L$. sibiricum. Three of these (L. gracile, $L$. sinoprocerum, $L$. sinense) have been reported only from China (Lu et al. 2008; Paciura et al. 2010; and isolates from the present study). Leptographium longiconidiophorum and L. pini-densiflorae have been recorded only from Japan (Masuya et al. 2000; present study), while $L$. bhutanense is from Bhutan (Zhou et al. 2008), and $L$. sibiricum from Russia (Jacobs et al. 2000). Most of these species were isolated from pines, but $L$. gracile (in Group A) has also been collected on spruce (Paciura et al. 2010), and L. sibiricum (in Group C) was isolated from Abies (Jacobs et al. 2000). The insects associated with species in Groups $\mathrm{A}$ and $\mathrm{C}$ are mainly weevils and bark beetles, with $L$. sibiricum being the only exception and collected as an associate of a cerambycid beetle (Jacobs et al. 2000). Pathogenicity has been tested for only $L$. sinoprocerum residing in the Asian lineages. This species was thought to be less pathogenic than the other fungal associates of $D$. valens based on the lesions resulting from inoculations in the crowns of mature P. tabuliformis in China (Lu et al. 2009b).

The two new species described in the present study were both isolated from Pinus spp. Of these, $L$. longiconidiophorum was from P. densiflora in Japan adding to several species in Leptographium $s$. $l$. reported in association with various bark beetles from P. densiflora in Japan, including L. procerum (Masuya et al. 1999, 2009). All these identifications have been based on morphology, and although L. longiconidiophorum has longer conidiophores than $L$. procerum, it is possible that some of the isolates reported from Japan as the latter species, might have represented $L$. longiconidiophorum.

The other new species, L. sinense, was isolated from the pine weevil Hylobitelus xiaoi infesting $P$. elliottii in China. This tree is native to the southeastern 
United States, and was introduced to China in the 1940s (Wen et al. 2004). During last 30 years, $P$. elliottii has become the dominant pine species in commercial plantations in southern China due to its fast growth rate and economic value (Wen et al. 2004). Hylobitelus xiaoi, which is native to China (Zhang 1997), has become known as a common pest in over 80,000 ha of pine forests, including P. elliottii, in this country (Wen et al. 2004). The weevil has contributed to the mortality of over 15,000 pine seedlings in Jiangxi Province alone (Wen et al. 2004). These weevils breed in healthy hosts, where the larvae invade the inner bark of the lower stem while the adults infest the inner bark of branches (Wen et al. 2004). The isolates in the present study originated from both the larvae and adults of $H$. xiaoi, as well as their galleries. As the fungal associates of $H$. xiaoi have not previously been studied, $L$. sinense is the first ophiostomatoid fungus reported in association with this insect. Although the insect is exotic to China, the phylogenetic placement of $L$. sinense in the Asian lineage of the $L$. procerum complex, suggests that the fungus might be native to China.

The availability of DNA sequencing techniques that distinguish between cryptic species, has led to the discovery of new species in the L. procerum complex. Of the nine species recognized in the complex, the majority were described for the first time from Asia, and all except $L$. profanum have been recorded from this continent. Current knowledge thus suggests that East Asia could be the center of species diversity in the $L$. procerum complex. Yet very little is known regarding the biology, ecology and population genetics of these fungi. It will be interesting to obtain more samples of species in this complex from Europe, America and other continents in the future, to understand more clearly their origins, diversity, host range, and pathways of movement.

Acknowledgments This study was initiated through the bilateral agreement between the Governments of South Africa and China, and we are grateful for the funding via projects 2012DFG31830 (International Science \& Technology Cooperation Program of China), 2010KJCX015-03 (Forestry Science and Technology Innovation Project of Guangdong Province of China). We acknowledge members of Tree Protection and Cooperation Programme (TPCP), the National Research Foundation (NRF), the Department of Science and Technology (DST)/NRF, Center of Excellence in Tree Health Biotechnology (CTHB) and the University of Pretoria, Pretoria, South Africa. We also thank Mr. Runlei Chang for assistance with the fieldwork, and Ms. Yalin Fu for assistance with fungal isolations.

\section{References}

Alexander SA, Horner WE, Lewis KJ (1988) Leptographium procerum as a pathogen on pines. In: Harrington TC, Cobb FW Jr (eds) Leptographium root disease on conifers. The American Phytopathological Society Press, St. Paul, pp 97-122

Cognato AI, Sun J-H, Anducho-Reyes MA, Donald RO (2005) Genetic variation and origin of red turpentine beetle (Dendroctonus valens LeConte) introduced to the People's Republic of China. Agric For Entomol 7:87-94

De Beer ZW, Wingfield MJ (2013) Emerging lineages in the Ophiostomatales. In: Seifert KA, De Beer ZW, Wingfield MJ (eds) The ophiostomatoid fungi: expanding frontiers, CBS biodiversity series 12 . CBS Press, Utrecht, pp 21-46

DiGuistini S, Wang Y, Liao NY, Taylor G, Tanguay P, Feau N, Henrissat B, Chan SK, Hesse-Orce U, Alamouti SM, Tsui CKM, Docking RT, Levasseur A, Haridas S, Robertson G, Birol I, Holt RA, Marra MA, Hamelin RC, Hirst M, Jones SJM, Bohlmann J, Breuil C (2011) Genome and transcriptome analyses of the mountain pine beetle-fungal symbiont Grosmannia clavigera, a lodgepole pine pathogen. PNAS 108:2504-2509

Duong TA, De Beer ZW, Wingfield BD, Wingfield MJ (2012) Phylogeny and taxonomy of species in the Grosmannia serpens complex. Mycologia 104:715-732

Duong TA, De Beer ZW, Wingfield BD, Wingfield MJ (2013) Characterization of the mating-type genes in Leptographium procerum and Leptographium profanum. Fungal Biol 117:411-421

Duong TA, De Beer ZW, Wingfield BD, Eckhardt LG, Wingfield MJ (2014) Microsatellite and mating type markers reveal unexpected patterns of genetic diversity in the pine root infecting fungus Grosmannia alacris. Plant Pathol. doi:10.1111/ppa.12231

Glass NL, Donaldson GC (1995) Development of primer sets designed for use with the PCR to amplify conserved genes from filamentous ascomycetes. Appl Environ Microbiol 61:1323-1330

Goidànich (1936) II genere di Ascomiceti 'Grosmanni' G. Goid. Boll Stn Patol Veg Roma 16:26-40

Grobbelaar JW, De Beer ZW, Bloomer P, Wingfield MJ, Wingfield BD (2010) Ophiostoma tsotsi sp. nov., a woundinfesting fungus of hardwood trees in Africa. Mycopathol 169:413-423

Guindon S, Dufayard JF, Lefort V, Anisimova M, Hordijk W, Gascuel O (2010) New algorithms and methods to estimate maximum-likelihood phylogenies: assessing the performance of PhyML 3.0. Syst Biol 59:307-321

Hawksworth DL (2011) A new dawn for the naming of fungi: impacts of decisions made in Melbourne in July 2011 on the future publication and regulation of fungal names. IMA Fungus 2:155-162

Jacobs K, Wingfield MJ (2001) Leptographium species: tree pathogens, insect associates, and agents of blue-stain. The American Phytopathological Society Press, St. Paul 
Jacobs K, Wingfield MJ, Pashenova NV, Vetrova VP (2000) A new Leptographium species from Russia. Mycol Res 104:1524-1529

Jacobs K, Bergdahl DR, Wingfield MJ, Halik S, Seifert KA, Bright DE, Wingfield BD (2004) Leptographium wingfieldii introduced into North America and found associated with exotic Tomicus piniperda and native bark beetles. Mycol Res 108:411-418

Jacobs K, Eckhardt LG, Wingfield MJ (2006) Leptographium profanum sp. nov., a new species from hardwood roots in North America. Can J Bot 84:759-766

Jankowiak R (2006) Fungi associated with Tomicus piniperda in Poland and assessment of their virulence using Scots pine seedlings. Ann For Sci 63:801-808

Jankowiak R (2012) Ophiostomatoid fungi associated with Ips sexdentatus on Pinus sylvestris in Poland. Dendrobiology $68: 43-54$

Jankowiak R, Bilański P (2013a) Diversity of ophiostomatoid fungi associated with the large pine weevil, Hylobius $a$ bietis and infested Scots pine seedlings in Poland. Ann For Sci 70:391-402

Jankowiak R, Bilański P (2013b) Association of the pineinfesting Pissodes species with ophiostomatoid fungi in Poland. Eur J For Res 132:523-534

Jankowiak R, Bilański P (2013c) Ophiostomatoid fungi associated with root-feeding bark beetles in Poland. For Pathol 43:422-428

Jankowiak R, Kolařík M (2010) Diversity and pathogenicity of ophiostomatoid fungi associated with Tetropium species colonizing Picea abies in Poland. Folia Microbiol 55:145-154

Jankowiak R, Bilański P, Kolařík M, Wasiuta D (2012) Rootcolonizing ophiostomatoid fungi associated with dying and dead young Scots pine in Poland. For Pathol 42:492-500

Katoh K, Misawa K, Kuma K, Miyata T (2002) MAFFT: a novel method for rapid multiple sequence alignment based on fast Fourier transform. Nucleic Acids Res 30:3059-3066

Kendrick WB (1962) The Leptographium complex Verticicladiella hughes. Can J Bot 40:772-797

Kim GH, Kim JJ, Lim YW, Breuil C (2005) Ophiostomatoid fungi isolated from Pinus radiata logs imported from New Zealand to Korea. Can J Bot 83:272-278

Lackner AL, Alexander SA (1982) Occurrence and pathogenicity of Verticicladiella procera in Christmas tree plantations in Virgina. Plant Dis 66:211-212

Lagerberg T, Lundberg G, Melin E (1927) Biological and practical researches into blueing in pine and spruce. Sven Skogsvårdsfören Tidskr 25:145-272

Lim YW, Massoumi Alamouti S, Kim JJ, Lee S, Breuil C (2004) Multigene phylogenies of Ophiostoma clavigerum and closely related species from bark beetle-attacked Pinus in North America. FEMS Microbiol Lett 237:89-96

Linnakoski R, De Beer ZW, Duong TA, Niemelä P, Pappinen A, Wingfield MJ (2012) Grosmannia and Leptographium spp. associated with conifer-infesting bark beetles in Finland and Russia, including Leptographium taigense sp. nov. Antonie Van Leeuwenhoek 102:375-399

Lu Q, Decock C, Zhang XY, Maraite H (2008) Leptographium sinoprocerum sp. nov., an undescribed species associated with Pinus tabuliformis-Dendroctonus valens in northern China. Mycologia 100:275-290
Lu M, Zhou XD, De Beer ZW, Wingfield MJ, Sun JH (2009a) Ophiostomatoid fungi associated with the invasive pineinfesting bark beetle, Dendroctonus valens, in China. Fungal Divers 38:133-145

Lu Q, Decock C, Zhang XY, Maraite H (2009b) Ophiostomatoid fungi (Ascomycota) associated with Pinus tabuliformis infested by Dendroctonus valens (Coleoptera) in northern China and an assessment of their pathogenicity on mature trees. Antonie Van Leeuwenhoek 96:275-293

Lu M, Wingfield MJ, Gillette NE, Mori SR, Sun JH (2010) Complex interactions among host pines and fungi vectored by an invasive bark beetle. New Phytol 187:859-866

Masuya H, Kaneko S, Yamaoka Y, Ohsawa M (1999) Comparisons of ophiostomatoid fungi associated with Tomicus piniperda and T. minor in Japanese red pine. J For Res 4:131-135

Masuya H, Wingfield MJ, Kaneko S, Yamaoka Y (2000) Leptographium pini-densiflorae sp. nov. from Japanese red pine. Mycoscience 41:425-430

Masuya H, Kaneko S, Yamaura Y, Yamaoka Y (2009) Ophiostomatoid fungi isolated from Japanese red pine and their relationships with bark beetles. Mycoscience 50:212-223

Matusick G, Somers G, Eckhardt L (2012) Root lesions in large loblolly pine (Pinus taeda L.) following inoculation with four root-inhabiting ophiostomatoid fungi. For Pathol 42:37-43

Miao ZW, Chou WM, Huo FY, Wang XL, Fang JX, Zhao MM (2001) Biology of Dendroctonus valens in Shanxi province. Shanxi For Sci Technol 23:34-37

O'Donnell K, Cigelnik E (1997) Two divergent intragenomic rDNA ITS2 types within a monophyletic lineage of the fungus Fusarium are nonorthologous. Mol Phylogent Evol 7:103-116

Paciura D, De Beer ZW, Jacobs K, Zhou XD, Ye H, Wingfield MJ (2010) Eight new Leptographium species associated with tree-infesting bark beetles in China. Persoonia 25:94-108

Posada D (2008) jModelTest: phylogenetic model averaging. Mol Biol Evol 25:1253-1256

Rambaut A, Drummond AJ (2007) Tracer 1.4. Available at http://tree.bio.ed.ac.uk/software/tracer/. Accessed $12 \mathrm{Dec}$ 2014

Rayner RW (1970) A mycological color chart. CMI and British Mycological Society, Kew

Robert V, Vu D, Amor AB, van de Wiele N, Brouwer C, Jabas B, Szoke S, Dridi A, Triki M, Ben Daoud S, Chouchen O, Vaas L, de Cock A, Stalpers JA, Stalpers D, Verkley GJ, Groenewald M, Dos Santos FB, Stegehuis G, Li W, Wu L, Zhang R, Ma J, Zhou M, Gorjon SP, Eurwilaichitr L, Ingsriswang S, Hansen K, Schoch C, Robbertse B, Irinyi L, Meyer W, Cardinali G, Hawksworth DL, Taylor JW, Crous PW (2013) MycoBank gearing up for new horizons. IMA Fungus 4:371-379

Robinson-Jeffrey RC, Davidson RW (1968) Three new Europhium species with Verticicladiella imperfect states on blue-stained pine. Can J Bot 46:1523-1527

Ronquist F, Teslenko M, van der Mark P, Ayres DL, Darling A, Höhna S, Larget B, Liu L, Suchard MA, Huelsenbeck JP (2012) MrBayes 3.2: efficient bayesian phylogenetic inference and model choice across a large model space. Syst Biol 61:539-542 
Schoch CL, Seifert KA, Huhndorf S, Robert V, Spouge JL, Levesque CA, Chen W, Bolchacova E, Voigt K, Crous PW (2012) Nuclear ribosomal internal transcribed spacer (ITS) region as a universal DNA barcode marker for fungi. PNAS 109:6241-6246

Shaw C, Dick M (1979) Verticicladiella root disease of Pinus strobus in New Zealand. Plant Dis 64:96-98

Sun JH, Lu M, Gillette NE, Wingfield MJ (2013) Red turpentine beetle: innocuous native becomes invasive tree killer in China. Annu Rev Entomol 58:293-311

Swofford DL (2003) PAUP* 4.0: phylogenetic analysis using parsimony (*and other methods). Sinauer Associates, Sunderland, Massachusetts

Taerum SJ, Duong TA, De Beer ZW, Gillette N, Sun JH, Owen DR, Wingfield MJ (2013) Large shift in symbiont assemblage in the invasive red turpentine beetle. PLoS One 8:e78126

Tamura K, Peterson D, Peterson N, Stecher G, Nei M, Kumar S (2011) MEGA5: molecular evolutionary genetics analysis using maximum likelihood, evolutionary distance, and maximum parsimony methods. Mol Biol Evol 28: 2731-2739

Wen X, Kuang Y, Shi M, Li H, Luo Y, Deng R (2004) Biology of Hylobitelus xiaoi (Coleoptera: Curculionidae), a new pest of slash pine, Pinus elliottii. J Econ Entomol 97: 1958-1964

White TJ, Bruns T, Lee S, Taylor J (1990) Amplification and direct sequencing of fungal ribosomal RNA genes for phylogenetics. In: Innis MA, Gelfand DH, Snisky JJ, White TJ (eds) PCR protocols: a guide to methods and applications. Academic Press, New York, pp 315-322

Wingfield MJ (1985) Reclassification of Verticicladiella based on conidial development. Trans Br Mycol Soc 85:81-93

Wingfield MJ (1986) Pathogenicity of Leptographium procerum and L. terebrantis on Pinus strobus seedlings and established trees. Eur J For Pathol 16:299-308
Wingfield MJ (1993) Leptographium species as anamorphs of Ophiostoma: Progress in establishing acceptable generic and species concepts. In: Wingfield MJ, Seifert KA, Webber JF (eds) Ceratocystis and Ophiostoma: taxonomy, ecology and pathogenicity. The American Phytopathological Society Press, St. Paul, pp 43-51

Wingfield MJ, Gibbs JN (1991) Leptographium and Graphium species associated with pine-infesting bark beetles in England. Mycol Res 95:1257-1260

Wingfield MJ, Marasas WFO (1983) Some Verticicladiella species, including $V$. truncata sp. nov., associated with root diseases of pine in New Zealand and South Africa. Trans Br Mycol Soc 80:231-236

Wingfield MJ, Capretti P, Mackenzie M (1988) Leptographium spp. as root pathogens of conifers. An international perspective. In: Harrington TC, Cobb FW Jr (eds) Leptographium root disease on conifers. The American Phytopathological Society Press, St. Paul, pp 113-128

Yamaoka Y, Masuya H, Chung WH, Goto H, To-Anun C, Tokumasu S, Zhou XD, Wingfield MJ (2008) The teleomorph of Leptographium yunnanense, discovered in crosses among isolates from Thailand, China, and Japan. Mycoscience 49:233-240

Zhang R (1997) Description of a new species Hylobitelus xiaoi (Coleoptera: Curculionidae). Sci Silvae Sin 33:541-545

Zhou XD, De Beer ZW, Wingfield BD, Wingfield MJ (2001) Ophiostomatoid fungi associated with three pine-infesting bark beetles in South Africa. Sydowia 53:290-300

Zhou XD, Jacobs K, Kirisits T, Chhetri DB, Wingfield MJ (2008) Leptographium bhutanense sp. nov., associated with the root collar weevil Hylobitelus chenkupdorjii on Pinus wallichiana in Bhutan. Persoonia 21:1-8

Zipfel RD, De Beer ZW, Jacobs K, Wingfield BD, Wingfield MJ (2006) Multi-gene phylogenies define Ceratocystiopsis and Grosmannia distinct from Ophiostoma. Stud Mycol 55:75-97 
CGATCCCGAGCTTCAGCACATCTCCCTTTCCATCTATCCGCCATCACTGTCTATCTGTCCACCGCCTCACTGCTTTGACGTCTCACGTCTGGCTCACTTGCCCGGCGAGATGAGCTGAGGACAGATCA

Exon 2

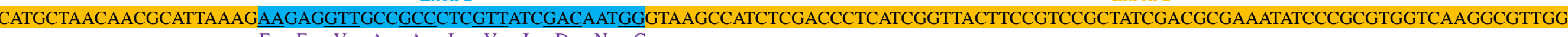
E E V V A

Exon 3

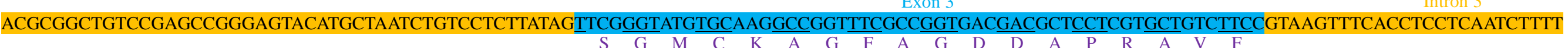

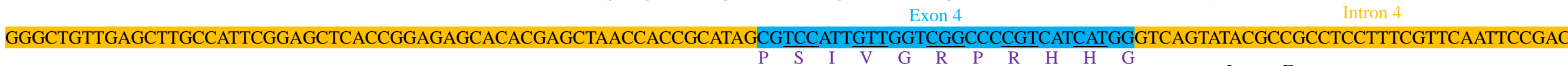

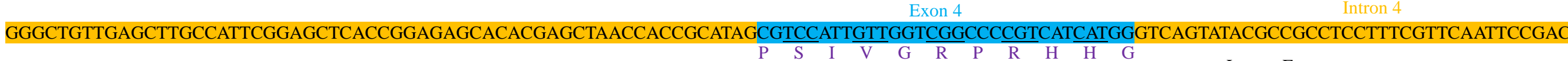
G

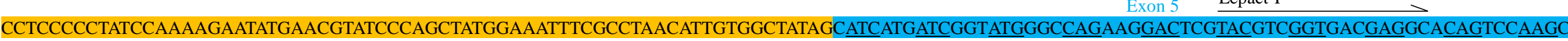

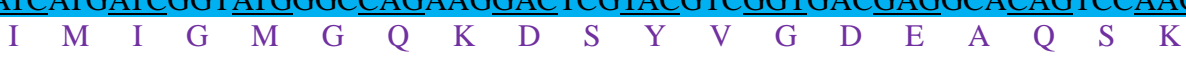

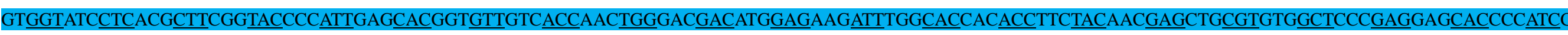

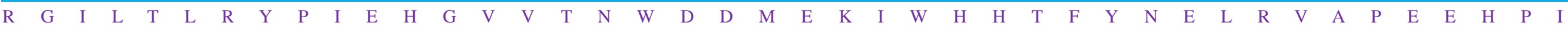

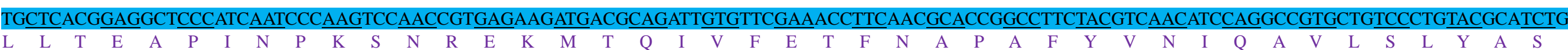

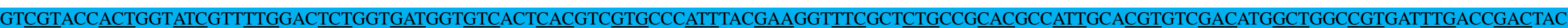

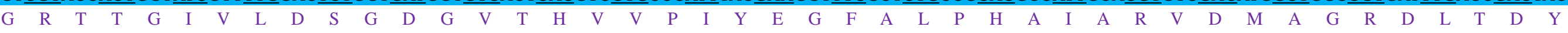

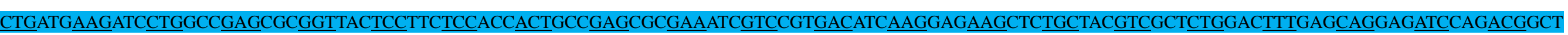

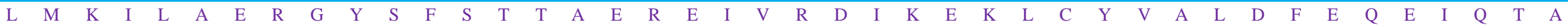

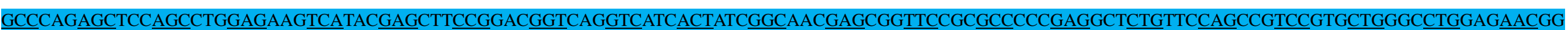

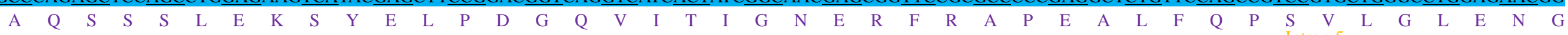

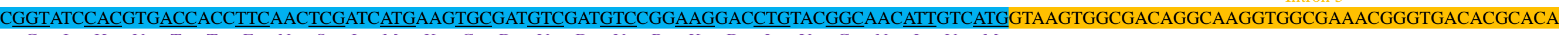

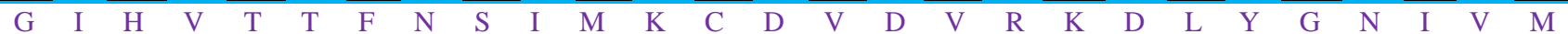

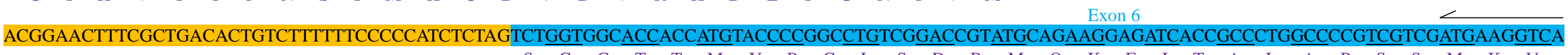
Lepact-R

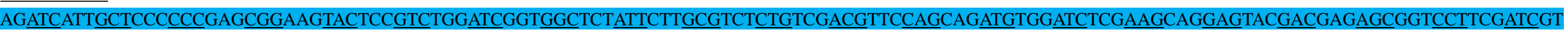

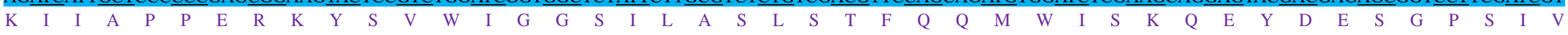
TCACCGCAAGTGCTTCTAA

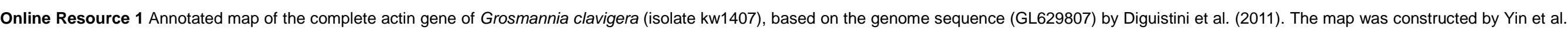
(2014) and the annotated sequence redeposited in Genbank as KP171180. Primers used for amplification in the study by Yin et al. (2014) are indicated with arrows. * represents the stop codon.

DiGuistini S, Wang Y, Liao NY, et al. (2011). Genome and transcriptome analyses of the mountain pine beetle-fungal symbiont Grosmannia clavigera, a lodgepole pine pathogen. PNAS 108:2504-2509.

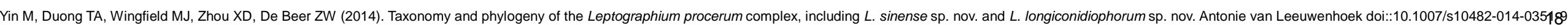



M E R I

TCGGTGCCTGTCCGACATCGTTTGCACTCCGGGTTTTTGACCCGTTTGCTTGATCTTGATCTCGAATCTCGTTGTCGATGGGCCTGGGGAAGGGACATATCTGTGTCCACTTGACTTGCGACCTGGAGAC $\underline{T 10}$ Exon 2

AACGAGAACATTTCTTGATAGCAGAAGTGCCAGCTGCCTTCACGTTGTGTCCTACACAGATTCGAGAATCTCAACTAACGTTTTAACAGGTCCACCTCCAGACTGGCCAATGCGTACGTTTCGCCCTACT $\begin{array}{lllll}\text { Intron } 2 & \text { Bt2a } & \text { Exon } 3 & \text { L Q T G Q C }\end{array}$

CCGAATCAATCGACCCCTACAGGCCCCCAGGCTCCGACGAAACAAACCTTAAACTGACACGGGCTATGGCATAACAG $\stackrel{\text { GGTAACAGATCGGTGCCGCTTTCTGGTAAGTTTTATCTGAGCTATAAATAAC }}{\mathrm{G}}$ Intron 3 Exon 4

GCATCTGGGCAATCAGCTTGAAGTGACAAATTCTAACCTACTTCACAGGCAGCAGATCTCCAGCGAGCACGGTCTCGACAGCAATGGAGTGTAGGTTTCCGGTTTCGGAAGAGTCTATTGTGGTGTATAT $\begin{array}{llllllllllllllll}\text { Exon } 5 & \text { Q } & \text { Q } & \text { I } & \text { S } & \text { G } & \text { E } & \text { H } & \text { G } & \text { L } & \text { D } & \text { S } & \text { N } & \text { G } & \text { V } & \text { Exon } 6\end{array}$

CATCTAATATGTTCTATCAGGTACAACGGCACGTCTGAGCTCCAGCTGGAGCGTATGAGCGTGTACTTCAACGAGGCCTCGGGCAACAAGTATGTGCCCCGCGCCGTCCTGGTCGATCTCGAGCCCGGC

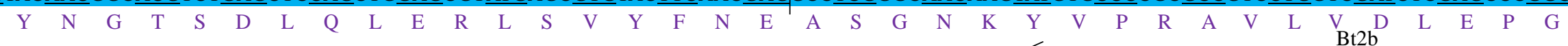

ACAATGGATGCTGTGCGCGCCGGTCCTTTCGGACAGCTCTTCCGGCCTGACAACTTCGTTTTCGGCCAGTCGGGTGCCGGCAACAACTGGGCCAAGGGTCACTACACGGAGGGTGCCGAGCTTGTGGA

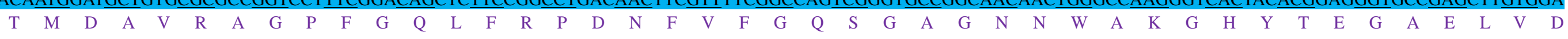

CCAGGTGCTCGACGTCGTCCGCCGCGAGGCTGAGGGCTGTGACAGCCTCCAGGGCTTCCAGATCACGCACTCCCTGGGCGGTGGCACGGGTGCCGGTATGGGCACCCTGCTAATCTCCAAGATCCGCG

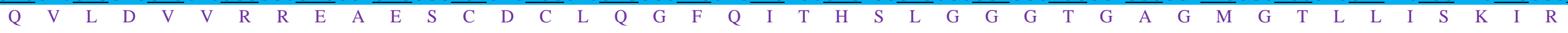

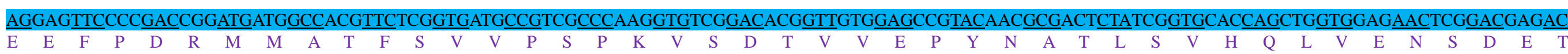

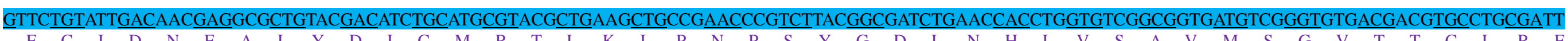

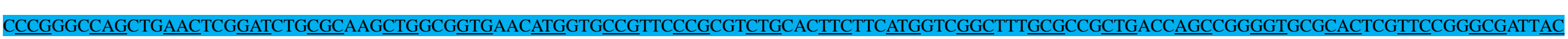

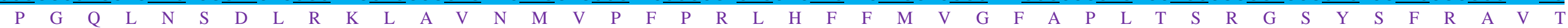

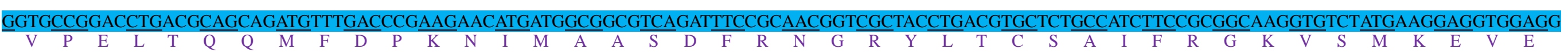

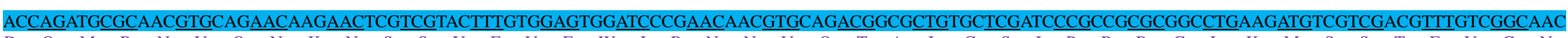

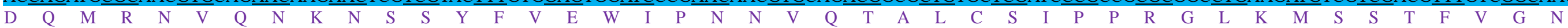

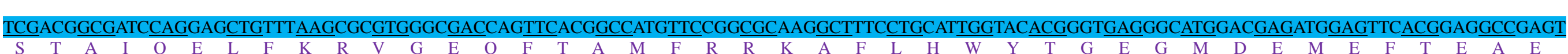

CCAACATGAACGATCTTGTCTCAGAATACCAGCAGTACCAGGATGCCGGTGTGGACGAGGACGAGGAGGAGTACGGTGTTGAGGAGGATGGTGTTGAGGAGCACGAGTAA

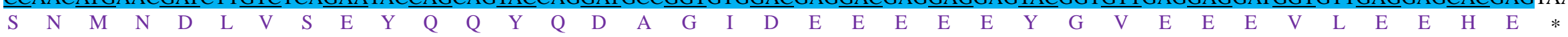

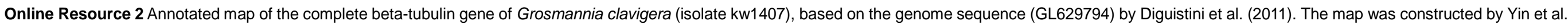

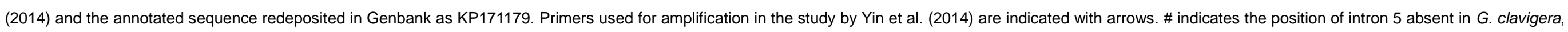
but present in some other species in the Ophiostomatales (De Beer and Wingfield 2013). * represents the stop codon.

De Beer ZW, Wingfield MJ (2013) Emerging lineages in the Ophiostomatales. In: Seifert KA, De Beer ZW, Wingfield MJ (eds) The Ophiostomatoid fungi: Expanding Frontiers. CBS Press, Utrecht, The Netherlands, pp 21-46

DiGuistini S, Wang Y, Liao NY, et al. (2011). Genome and transcriptome analyses of the mountain pine beetle-fungal symbiont Grosmannia clavigera, a lodgepole pine pathogen. PNAS 108:2504-2509. 


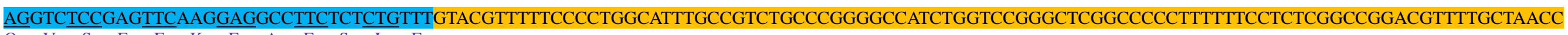

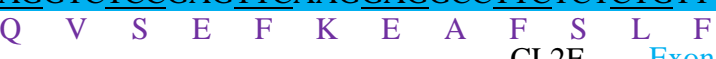

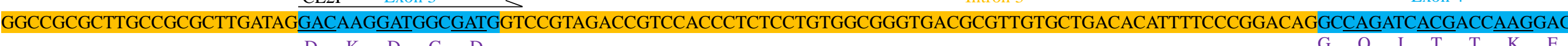
D $\quad K \quad D \quad G \quad D$

G Q I $\frac{\text { T }}{\mathrm{T}} \quad \mathrm{K}$ E

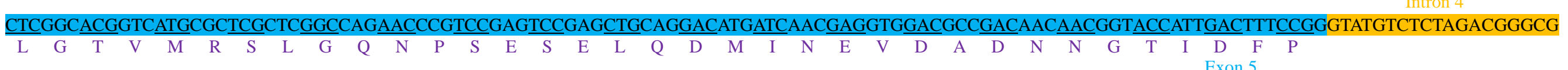

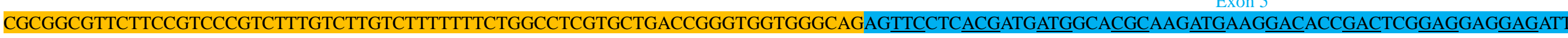

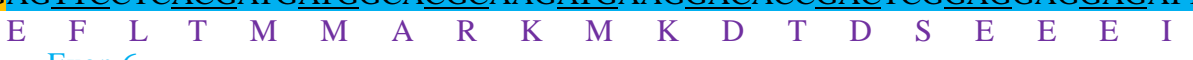

Exon 6

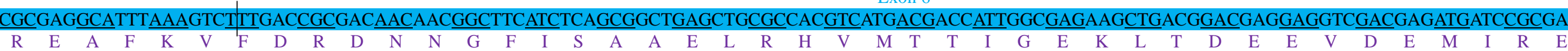

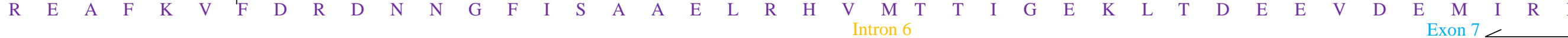

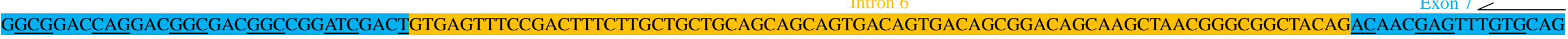

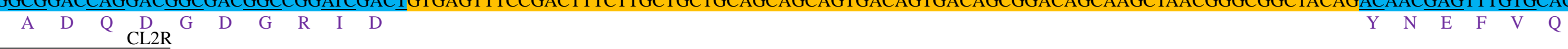
CTCATGATGCAGAAATAA

$\mathrm{L} M \mathrm{M}$ Q K *

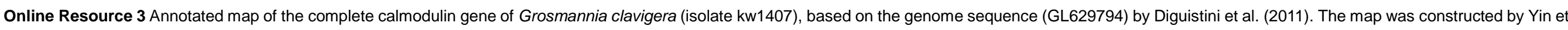

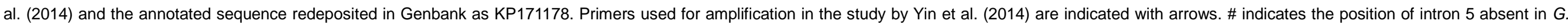
clavigera, but present in some other species in the Ophiostomatales (De Beer and Wingfield 2013). * represents the stop codon.

De Beer ZW, Wingfield MJ (2013) Emerging lineages in the Ophiostomatales. In: Seifert KA, De Beer ZW, Wingfield MJ (eds) The Ophiostomatoid fungi: Expanding Frontiers. CBS Press, Utrecht, The Netherlands, pp 21-46

DiGuistini S, Wang Y, Liao NY, et al. (2011). Genome and transcriptome analyses of the mountain pine beetle-fungal symbiont Grosmannia clavigera, a lodgepole pine pathogen. PNAS 108:2504-2509.

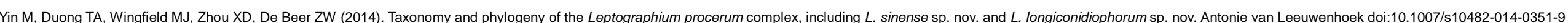


GCTAACCACATATGTCTACAGTAAGGAGGAGAAGCCGCATATCAACGTAAGTTTACGATCATATCGATCCGCCGTCCATTAACGCTCTGCTCGTCGCTGCCTTTCGTCCAACTCGAAAGCATCGAGCT

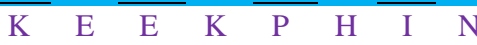

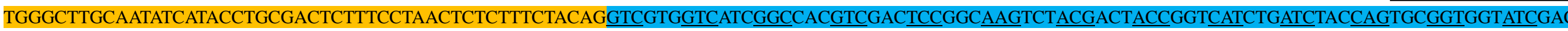

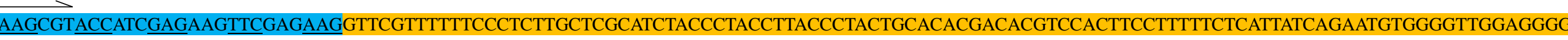

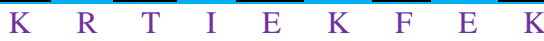

Intron 3

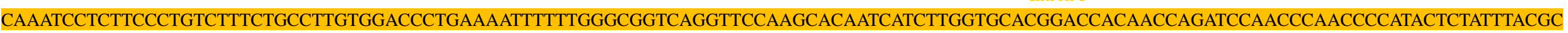
Exon 4

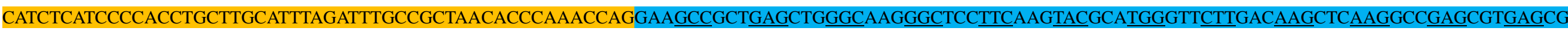

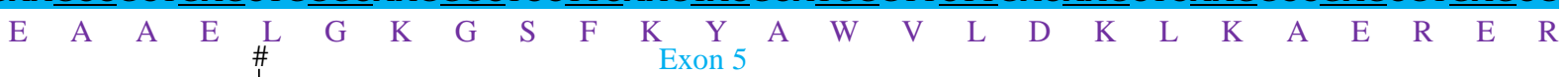

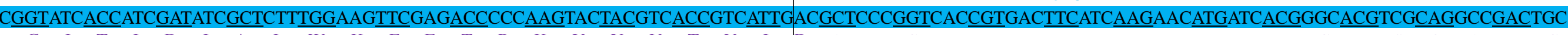

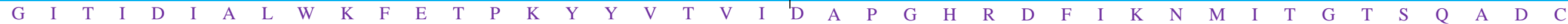

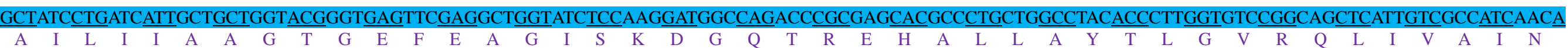

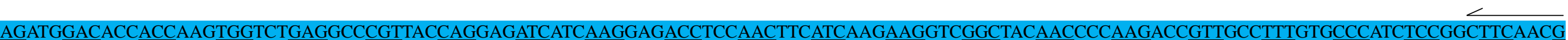

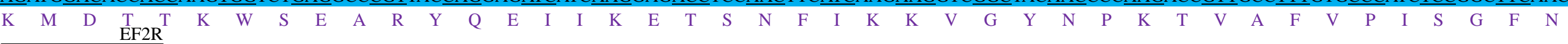

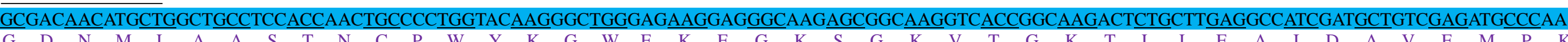

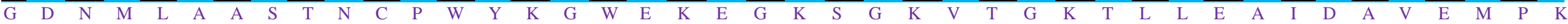

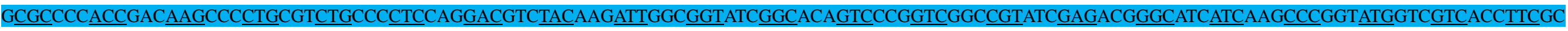

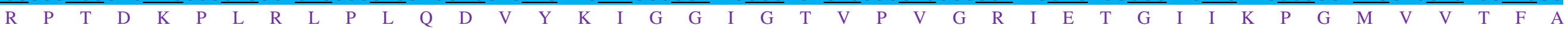

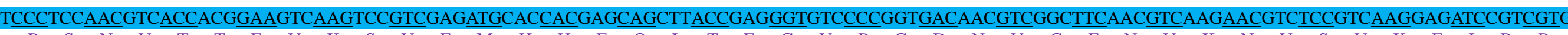

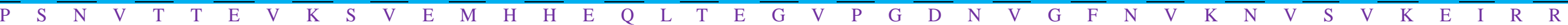

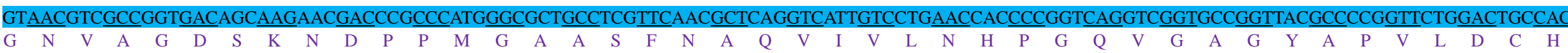

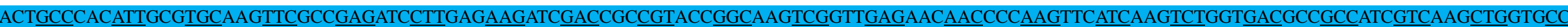

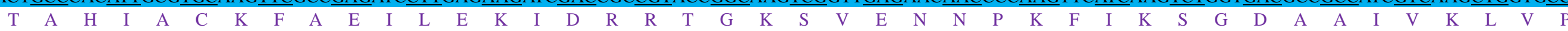

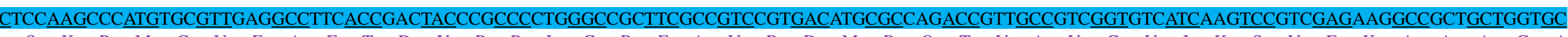

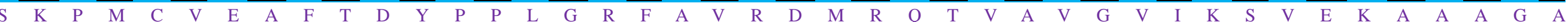
CGCC吕GTCACCAAGTCGGCTGCCAAGGCTGCCAAGAAATAG

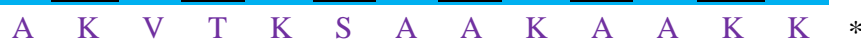

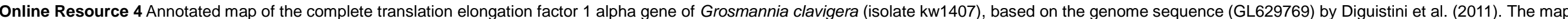

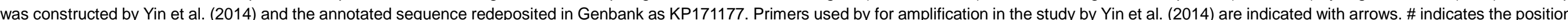
of intron 4 absent in G. clavigera, but present in some other species in the Ophiostomatales (De Beer and Wingfield 2013). * represents the stop codon.

De Beer ZW, Wingfield MJ (2013) Emerging lineages in the Ophiostomatales. In: Seifert KA, De Beer ZW, Wingfield MJ (eds) The Ophiostomatoid fungi: Expanding Frontiers. CBS Press, Utrecht, The Netherlands, pp 21-46

DiGuistini S, Wang Y, Liao NY, et al. (2011). Genome and transcriptome analyses of the mountain pine beetle-fungal symbiont Grosmannia clavigera, a lodgepole pine pathogen. PNAS 108:2504-2509. 

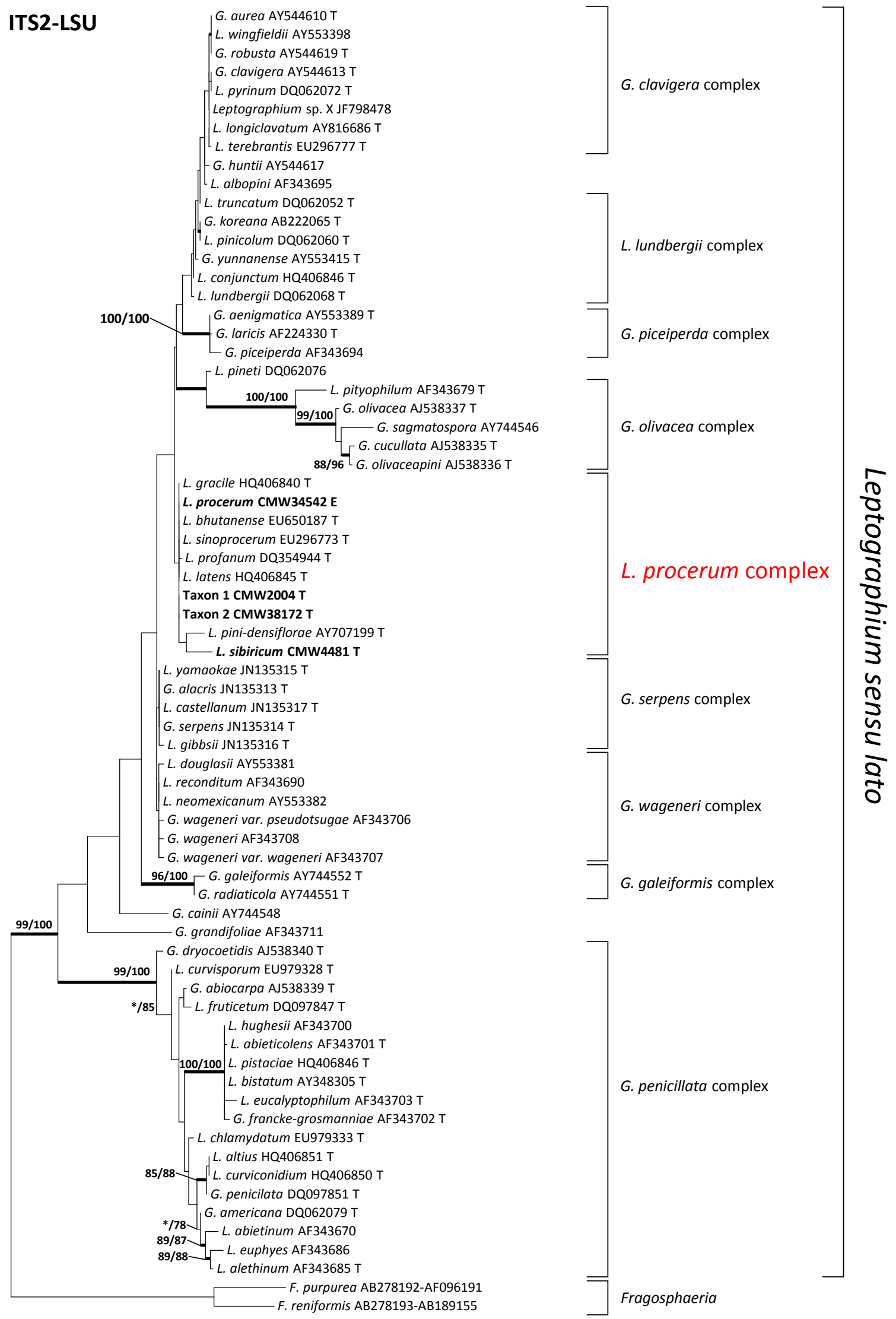

\section{G. wageneri complex \\ G. galeiformis complex}

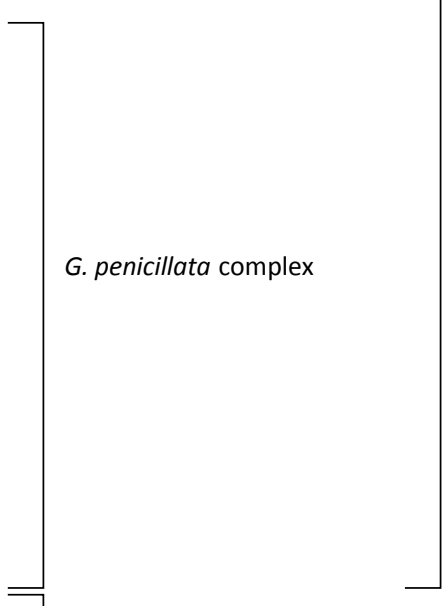

Fragosphaeria

Online Resource $5 \mathrm{ML}$ tree of Leptographium sensu lato generated from the ITS2-LSU DNA sequence data by Yin et al. (2014). Sequences generated from this study are printed in bold type. Bold branches indicate posterior probabilities values $\geq 0.95$. Bootstrap values $\geq 75 \%$ are recorded at nodes as ML/MP. * bootstrap values $<75 \%$. T ex-type isolate. E ex-epitype isolate 


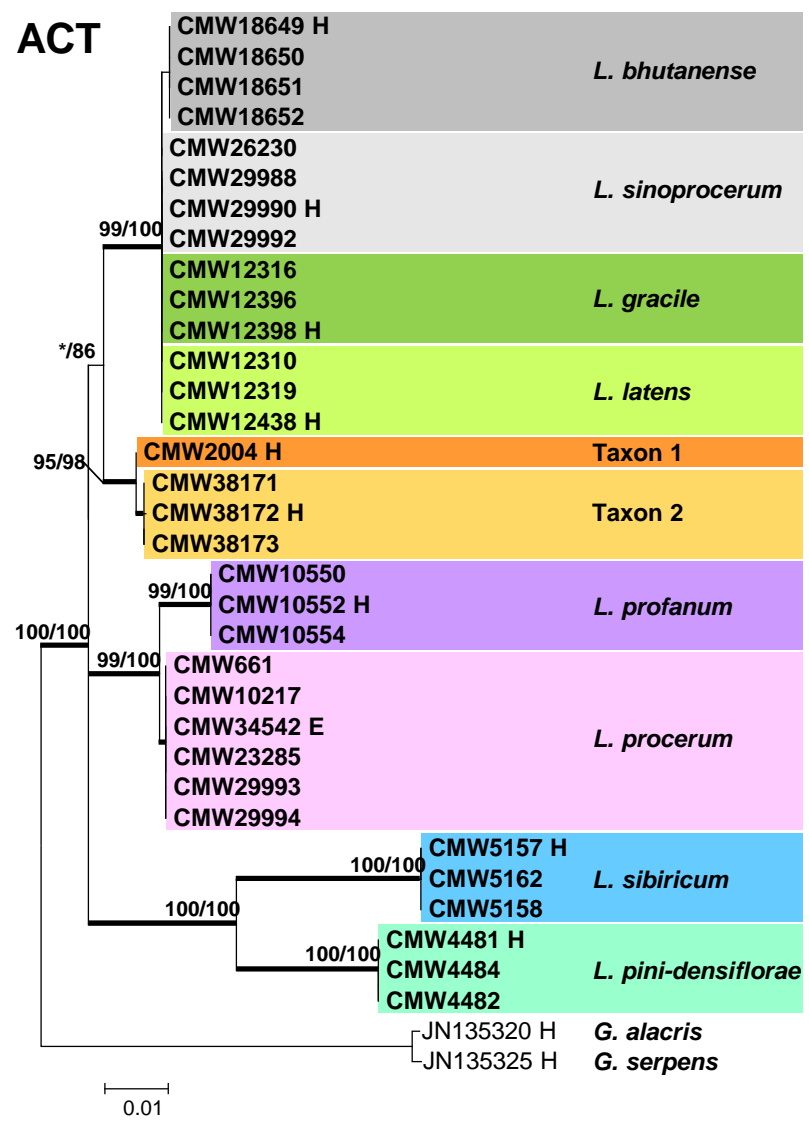

BT

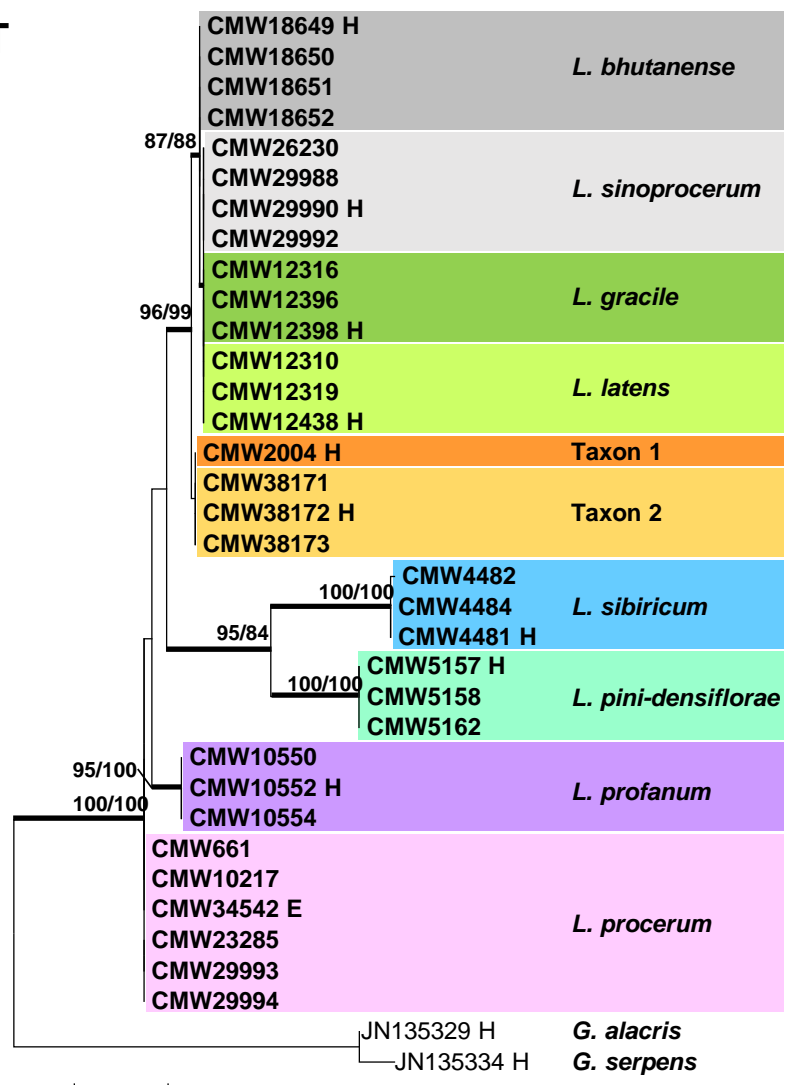

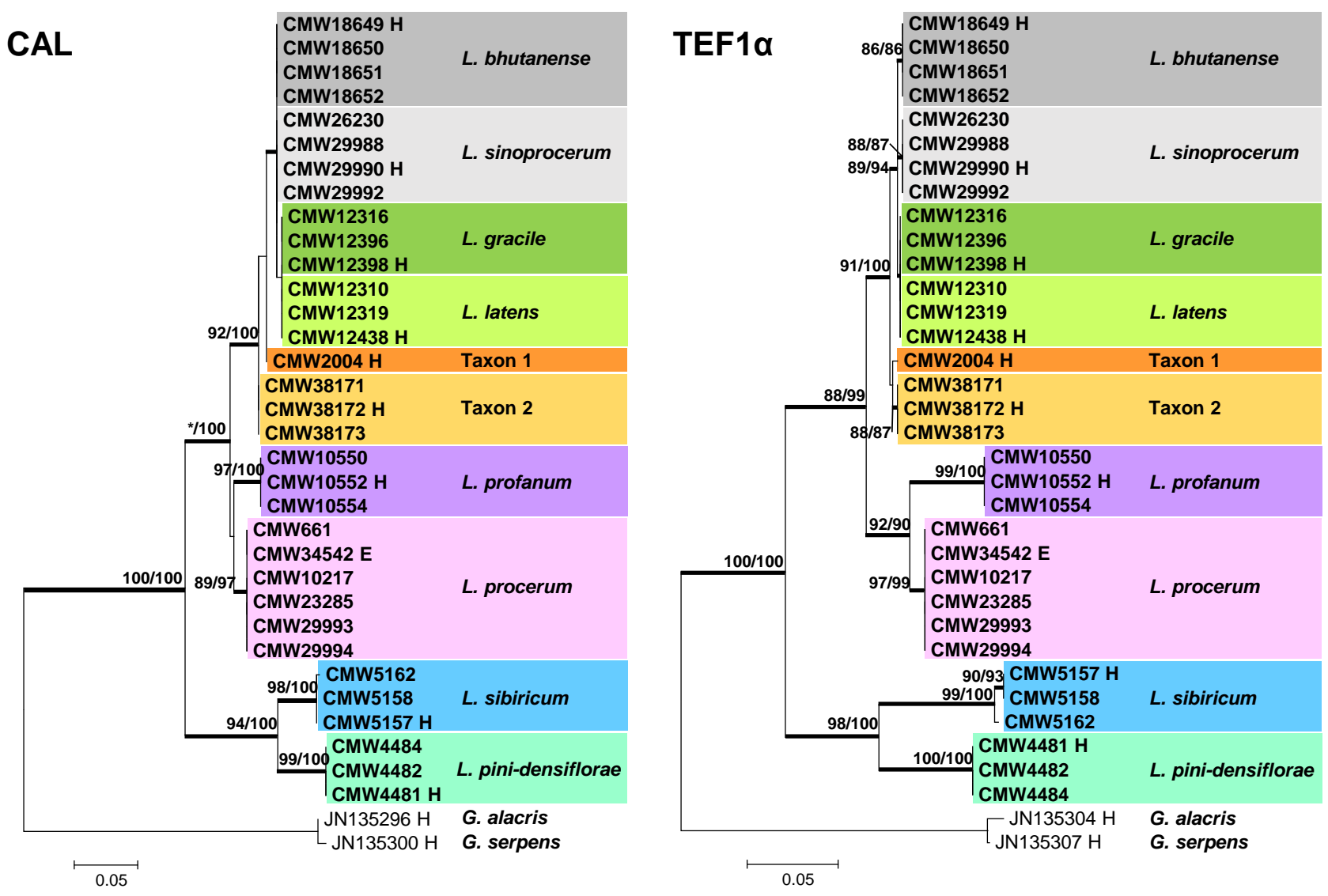

Online Resource $6 \mathrm{ML}$ trees of the Leptographium procerum complex generated from DNA sequences of four protein-coding gene regions by Yin et al. (2014). Bold branches indicate posterior probabilities values $\geq 0.95$. Bootstrap values $\geq 75 \%$ are recorded at nodes as ML/MP. * bootstrap values < 75\%. H ex-holotype isolate. E ex-epitype isolate

Yin M, Duong TA, Wingfield MJ, Zhou XD, De Beer ZW (2014). Taxonomy and phylogeny of the Leptographium procerum complex, including L. sinense sp. nov. and L. longiconidiophorum sp. nov. Antonie van Leeuwenhoek doi:10.1007/s10482-014-0351-9 


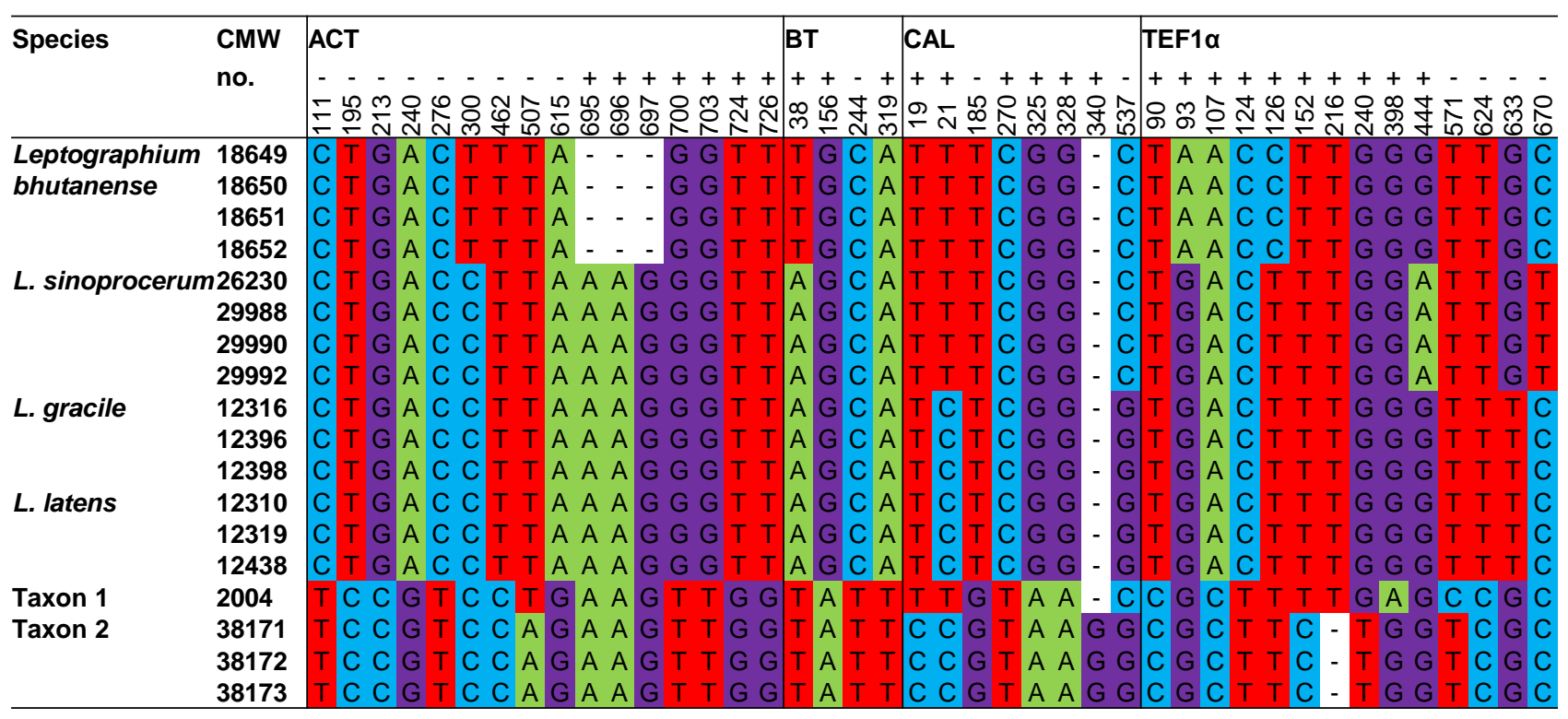

Online Resource 7 Comparison of polymorphic sites of protein-coding genes of doubtful and new species in the Leptographium procerum complex by Yin et al. (2014). Numbers above columns indicate the relative positions in the alignments. Symbol "-" indicates exons, while "+" represents intron regions in the various genes

Yin M, Duong TA, Wingfield MJ, Zhou XD, De Beer ZW (2014). Taxonomy and phylogeny of the Leptographium procerum complex, including $L$. sinense sp. nov. and L. longiconidiophorum sp. nov. Antonie van Leeuwenhoek doi:10.1007/s10482-014-0351-9 

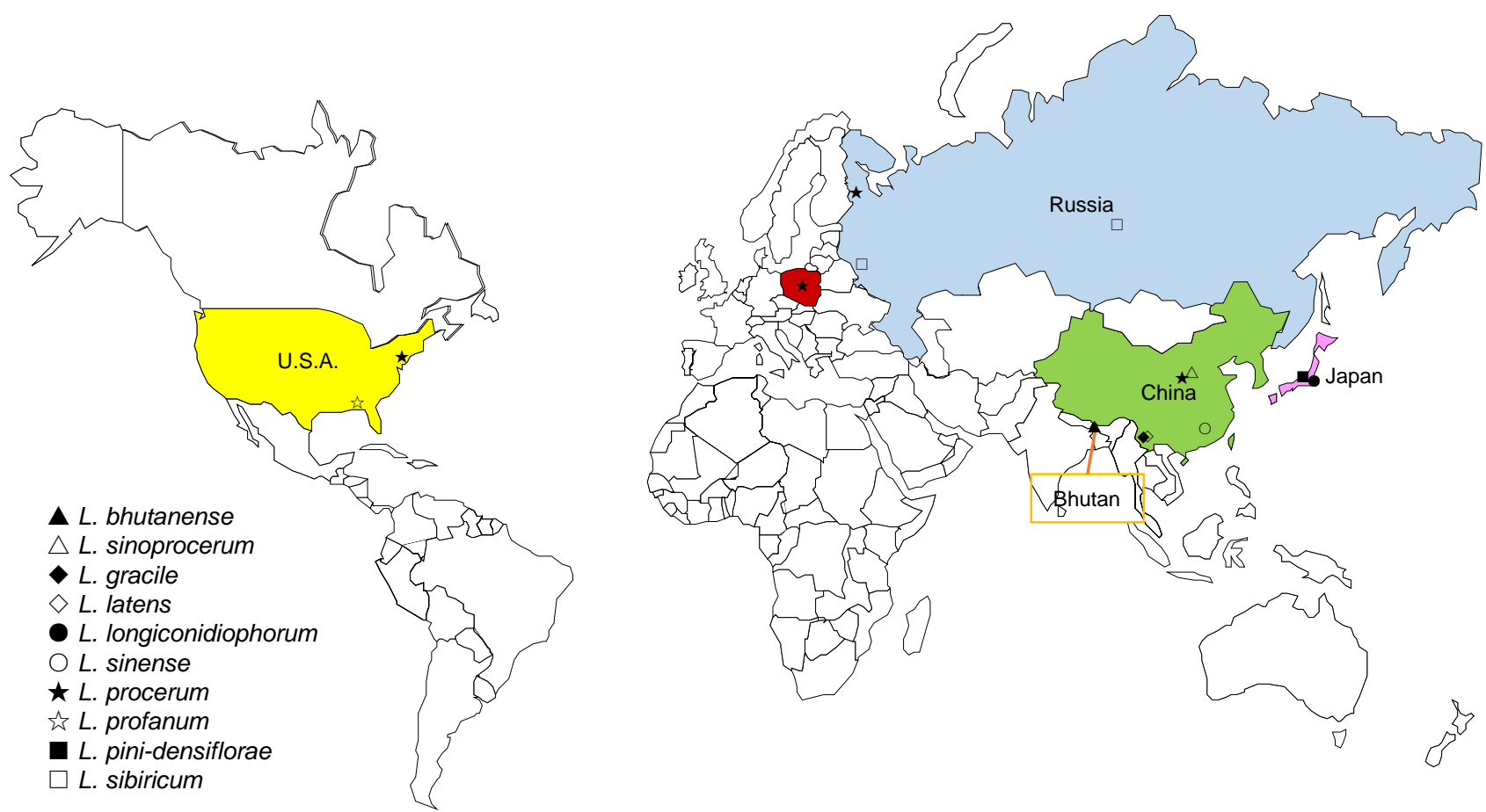

Online Resource 8 World map showing the distribution of species in the Leptographium procerum complex by Yin et al. (2014)

Yin M, Duong TA, Wingfield MJ, Zhou XD, De Beer ZW (2014). Taxonomy and phylogeny of the Leptographium procerum complex, including L. sinense sp. nov. and L. longiconidiophorum sp. nov. Antonie van Leeuwenhoek doi:10.1007/s10482-014-0351-9 